which we are well acquainted, namely, by the methods of care fully planned and patiently executed observation and experiment. The field for energetic and painstaking effort is wider and more attractive than ever before. Science is now truly cosmopolitan; it can be limited by no close corporations, and no domain of scientific investigation can be advantageously fenced off, either in time or in place, from the rest. While every active worker of this or of any affiliated society is, in a sense, a specialist, there are occasions when he should unite with his colleagues for the promotion of science as a whole. The results of the specialists need to be popularised and to be disseminated among the people at large. The advance of knowledge to be effective with the masses of our race must be sustained on its merits by a popular verdict. To bring the diverse scientific activities of the American continent into harmony for common needs; to secure cooperation for common purposes; and to disseminate the results of scientific investigation among our fellow men, are not less, but rather much more, than in the past the privilege and the duty of the American Association for the Advancement of Science.

Viewed, then, in its broader aspects, the progress of science is involved in the general progress of our race; and those who are interested in promoting the former should be equally earnest in securing the latter. However much we may be absorbed in the details of our specialities, when we stop to think of science in its entirety, we are led, in the last analysis, back to the problem of problems-the meaning of the universe. All men "gifted with the sad endowment of a contemplative mind" must recur again and again to this riddle of the centuries. We are, so to speak, whatever our prepossessions, all sailing in the same boat on an unknown sea for a destination at best not fully determined. Some there are who have, or think they have, the Pole Star always in sight. Others, though less confident of their bearings, are willing to assume nothing short of second place in the conduct of the ship. Others, still less confident of their bearings, are disposed to depend chiefly on their knowledge of the conpass and on their skill in dead reckoning. We of the latter class may not impugn the motives or doubt the sincerity of the first two classes. We would find it difficult, probably, to dispense with their company in so long a journey after becoming so well acquainted with them; for among them we may each recall not a few of those rarer individuals of the genus homo called angels on earth. But it must be said in all truth, to resume the figure, that they have neither improved much the means of transportation nor perfected much the art of navigation. They have been sufficiently occupied, perhaps, in allaying the fears of the timid and in restraining the follies of the mutinous. Other types of mind and other modes of thought than theirs have been essential to work out the improvements which separate the earlier from the later nautical equipments of men; such improvements, for example, as mark the distinction between the dug-out of our lately acknowledged relatives, the Moros and the Tagalogs, from the Atlantic-liner of to-day. At any rate, we are confronted by the fact that man's conceptions of the universe have undergone slow but certain enlargement. His early anthropocentric and anthropomorphic views have been replaced, in so far as he has attained measurable advancement, by views that will bear tests of astronomy and anthropology. He has learned, slowly and painfully, after repeated failures and many steps backward, to distinguish, in some regions of thought, the real and the permanent from the fanciful and fleeting phenomena of which he forms a part. His pursuit of knowledge, in so far as it has led him to certainty, has been chiefly a discipline of disillusionment. He has arrived at the truth not so much by the genius of direct discovery as by the laborious process of the elimination of error. Hence he who has learned wisdom from experience must look out on the problem of the universe at the beginning of the twentieth century with far less confidence in his ability to speedily solve it, and with far less exaggerated notions of his own importance in the grand aggregate of Nature, than man entertained at the beginning of our era. But no devotee of science finds humiliation in this departure from the primitive concepts of humanity. On the contrary, he has learned that this apparent humiliation is the real source of enlightenment and encouragement; for notwithstanding the relative minuteness of the speck of cosmic dust on which we reside, and notwithstanding the relative incompetency of the mind to discover our exact relations to the rest of the universe, it has yet been possible to measure that minuteness and to determine that incompetency.
These, in brief, are the elements of positive knowledge at which we have arrived through the long course of unconscious, or only half-conscious, experience of mankind. All lines of investigation converge towards or diverge from these elements. It is along such lines that progress has been attained in the past, and it is along the same lines that we may expect progress to proceed in the future.

\section{THE GLASGOW MEETING OF THE BRITISH ASSOCIATION}

THE seventy-first annual meeting of the British Association came to an end yesterday. For the purposes of the meeting the entire accommodation of the College Buildings was placed at the disposal of the Association by the University authorities, while for the opening meeting the St. Andrew's Hall was granted by the Corporation. Between 2000 and 3000 persons attended at the St. Andrew's Hall to hear the opening address of the president, Prof. A. W. Rücker, F.R.S. The retiring president, Sir William Turner, F.R.S., took the chair and introduced his successor, who afterwards delivered the presidential address, which was printed in last week's NATURE; and on Thursday morning the work of the sections commenced. Reports of the proceedings of the sections will appear in these columns as in previous years.

Melancholy interest was given to the meeting by the expressions of sympathy sent to the United States by the Association in connection with the assassination of the late President $M^{6}$ Kinley. At the first meeting of the General Committee, it was decided, upon the proposition of Sir Michael Foster, seconded by Sir John Evans, that the following telegram be sent on behalf of the Association :- "That the British Association for the Advancement of Science, assembled at Glasgow, desires to make known to President M'Kinley its feeling of horror at the attempt upon his life, its sympathy with him in his suffering, and its earnest hope for his speedy and complete restoration to health." A reply expressing thanks for the sympathy was received from the late President's: secretary on Thursday evening.

The news of the death of President $M^{\prime}$ Kinley became known on Saturday morning, when only two sections of the Association were sitting. At the close of the meeting of one of these sections-Educational Science-Sir John Gorst, the president, referred in touching terms to the profound grief which British people share with those of the United States at the terrible event that had occurred. The members present stood while expression was being given to their feelings by the president, and the following resolution, moved by him and seconded by Sir Philip Magnus, was adopted in solemn silence :-

"That this section of the British Association has heard with profound grief of the death of President M'Kinley, and records its deep sympathy with the family of the late President and the people of the United States of America in their domestic and national bereavement."

Many distinguished members of the Association were present at the opening by Lord Lister, on September I2, of the new Anatomical Department of Glasgow University, comprising an extensive laboratory, museum, \&c. The building has been presented to the University by the trustees of the late Mr. J. B. Thomson, and Lord Lister, in opening this important addition to the resources of the University, remarked that it comprised "as fine a laboratory as existed in the world, and at the same time a capacious, commodious, and beautiful anatomical museum adjoining it." Prof. Cleland has presented to the University his large collection of anatomical specimens, and this, with the specimens collected by his predecessors and placed in the museum, makes the 
anatomical department a place where work can be carried on under excellent conditions.

In considering the general success of the meeting, it must be borne in mind that many citizens of Glasgow had their scientific interests almost exhausted before the meeting began, by the International Engineering Congress which immediately preceded it. It is well understood locally that the many congresses and celebrations which have been held in Glasgow since last June supply the reason for the comparatively small attendance at this year's meeting of the Association. The first Glasgow meeting in 1855 was attended by 2I33 members and associates, and the total number present at the second meeting in 1876 was 2774 . This year, however, the attendance has scarcely reached I9oo. But the many claims which the City and Universities authorities have had upon their hospitality did not diminish the liberality of the welcome extended to the Association. Throughout the meeting the social as well as the scientific pleasures of the members have been attended to in the most generous manner. For instance, the reception given by the Corporation in the magnificent City Chambers will be remembered by everyone who attended it as one of the most brilliant yet given in honour of the Association.

Next year's meeting will be held at Belfast, and will begin on September I0, 1902. Prof. James Dewar, F.R.S., will be the president. The vice-presidents for the meeting will be the Marquis of Dufferin and Ava, the LordLieutenant of County Down, the Marquis of Londonderry, Sir Francis Macnaughten, the Lord-Lieutenant of County Antrim, the Right Honourable the Earl of Shaftesbury, the Right Honourable the Earl of Rosse, the Lord Mayor of Belfast, the president of Queen's College, Belfast ; Rev. Dr. Salmon, the president of Trinity College, Belfast ; Sir William Quartus Ewart, the Right Honourable Thomas Sinclair, and Prof. E. Ray Lankester, F.R.S.

The meeting in 1903 will be held at Southport.

The following is a synopsis of grants of money appropriated to scientific purposes by the General Committee at the meeting on Monday :-

\section{Mathematics and Physics.}

*Rayleigh, Lord-Electrical Standards

* Judd, Prof. J. W. - Seismological Observations ...

Shaw, Mr. W. N.-Investigation of the Upper Atmosphere by means of Kites...

Preece, Sir W.-Magnetic Observations at Falmouth $\ldots$ Chemistry.

*Hartley, Prof. W. N.-Relation between Absorption Spectra and Constitution of Organic Substances ... * Roscoe, Sir H. E. - Wave-length Tables

Roberts-Austen, Sir Wm. C.-Properties of Metals and Alloys affected by dissolved Gases

\section{Geology.}

* Marr, Mr. J. E.-Erratic Blocks ( $₫ 6$ in hand) ...

* Geikie, Prof. J.-Photographs of Geological Interest ...

* Marr, Mr. J. E. - Life-zones in British Carboniferous Rocks

*Watts, Prof. W. W. W.-Underground Water of North. West Yorkshire (balance in hand)

* Scharff, Dr.-Exploration of Irish Caves $\quad \ldots$.

* Woodward, Dr. H. - Type Specimens (balance in hand) Zoology.

"Herdman, Prof. W. A.-Table at the Zoological Station, $\begin{array}{llllllll}\text { Naples } & \ldots & \ldots & \ldots & \ldots & \ldots & \ldots & \ldots\end{array}$

${ }^{*}$ Garstang, Mr. W. - $\dddot{T}$ Table at the Biological Laboratory, Plymouth (balance $£ 85$ s. in hand) $\ldots$
Woodward, -Dr. H. - Index Generum Animalium...

* Newton, Prof. A. - Migration of Birds $\ldots$
"Sedgwick, Mr. A. - Structure of Coral Reefs of Indian

Region
Murray, Sir John. - Compound Ascidians of the Clyde

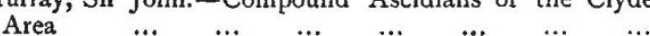

NO. I 664, voL. 64$]$
100

Geography.

*Keltie, Dr. J. Scott-Terrestrial Surface Waves

Economic Science and Statistics.

*Brabrook, Mr. E. W.-Legislation regulating Women's $\begin{array}{lllllllll}\text { Labour } & \ldots & \ldots & \ldots & \ldots & \ldots & \ldots & \ldots & 30\end{array}$

Mechanical Science.

* Preece, Sir W. H.-Small Screw Gauge (balance in hand and) $\ldots-\ldots \quad \ldots \quad \ldots$ Resistance of Road Vehicles to $\dddot{T}$ Traction Anthropology.

*Evans, Mr. A. J.-Silchester Excavation

* Penhallow, Prof. D. P.-Ethnological Survey of Canada

* Garson, Dr. J. G. - Age of Stone Circles...

* Read, Mr. C. H.-Photographs of Anthropological Interest (balance in hand)

*Tylor, Prof. E. B.-Anthropological Teaching ... $\quad \ldots$

* Evans, Sir John. - Exploration in Crete ... ... ... Native Egyptian Soldiers $\quad . . \quad \ldots$... Rhys, Prof. J.-Excavations on the Roman Site at Gelligae

$$
\text { Physiology. }
$$

McKendrick, Prof. J. G.-Changes in Hæmoglobin ... McKendrick, Prof. J. G.- Work of Mammalian Heart under influence of Drugs..

\title{
Botany.
}

Farmer, Prof. J. B.--Investigations of the Cyanophyceæ Marshall Ward, Prof. - The Respiration of Plants ...

\section{Educational Science.}

Armstrong, Dr. H. E.-Reciprocal Influence of Universities and Schools Conditions of Health essential to carrying on Work in Schools...

\section{Corresponding Societies.}

*Whitaker, Mr. W.-Preparation of Report

\section{SECTION B.}

\author{
CHEMistry.
}

Opening Address by Prof. Percy F. Frankland, Ph.D., M.Sc., F.R.S., President of The Section.

\section{The Position of British Chemistry at the Dawn of the Twentieth} Century.

Two circumstances unite in rendering this year especially ap propriate for the survey and valuation of all departments of British life and organisation-the dawn of a new century, the close of the Victorian era. It is a moment when not only the nation as a whole, but every group of persons drawn together by whatever bond, and indeed each individual for himself, must involuntarily ask the question, Are we progressing or receding, or are we standing still? Upon us, then, who are bound together by the common interest which we have in that science to which this Section is devoted there forces itself the question, What is the position of British Chemistry at the present moment, how does this present bear comparison with the past, and what are the prospects for the future?

To bring before you some considerations with respect to the answer which should be given to this question, or rather series of questions, will be my endeavour in responding to the honour which has been conferred on me of inaugurating the work of our Section at this meeting of the Association.

It is with no light heart that I undertake this task, for there are present here to-day those whose much longer experience and far more intimate connection with the progress of our science render it presumption on my part to address them on this subject at all.

It is well known that the history of British Chemistry, as, indeed, that of British science in general, is a very remarkable one : it is almost entirely made up of achievements which are the result of private initiative; and the persons who have taken part in the making of this history have, with some notable exceptions, not been servants of the State, and have thus differed from the 
makers of scientific history in almost every other country in the world. Thus the opportunities for the investigations which are recorded in the Transactions of our Chemical Society have, for the most part, not been provided out of the public purse, but by private individuals or by institutions which have been created by private benefaction.

This unique condition of things is well illustrated by taking up a volume of the Chemical Society's Tournal and glancing at the table of contents.

Thus in the volume for $188 \mathrm{r}$, taken at random, we find that, out of the seventy-five original communications which it contains, only thirteen emanate from Government laboratories, whilst what will surely not a little surprise the scientific historian of some centuries hence is the circumstance that there are only four communications from the so-called " ancient seats of learning" of the United Kingdom, no fewer than three of which are by one and the same investigator. Again, most noteworthy is the fact that as many as five contributions are from distinguished amateurs. We have been told, on what many persons regard as high authority, that England is suffering from amateurism in all departments of life; and however true this may be as a general proposition, the amateurs of British science, like Gladstone, Schunck and Perkin amongst living chemists, are assuredly some of the most valued possessions of this country.

On looking back a quarter of a century into the past it is at once apparent how greatly during that short period of time-less than a generation of men--have the opportunities for higher chemical training been extended and multiplied in our midst. I think I shall not be far wrong in saying that until twenty-five years ago practically the only public laboratories in which the higher study of chemistry could be pursued were those of the Royal College of Chemistry, the Royal Institution, of University and King's Colleges, London, the University laboratories of England, Scotland and Ireland, as well as those of the Queen's Colleges and of the Royal College of Science in the sister island ; to which must be added the laboratories of two institutions of a somewhat different type, viz. Owens College, Manchester, and Anderson's College, in this great city of the north. It is the rapid multiplication of institutions of the Owens College type that constitutes probably the most important feature in the higher intellectual development of the population of this country during the past quarter of a century; indeed, it may very possibly be found in the future that this constitutes the most striking landmark in the history of British intellectual progress during recent times. A glance at the following table will show the remarkably rapid growth of these institutions during the last quarter of the nineteenth century :-

\section{Opening of University Colleges.}

\begin{tabular}{|c|c|c|c|}
\hline & & & \\
\hline London & & & \\
\hline e, Manchester & & & \\
\hline am College of Science, New & castle & & 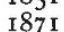 \\
\hline stwyth & $\ldots$ &. & \\
\hline e, Lee & & & \\
\hline ol... & & . & \\
\hline gham & . & .. & 8 \\
\hline fe & $\ldots$ & .. & I8 \\
\hline ham & .. & .. & \\
\hline &. & & \\
\hline & & $\ldots$ & \\
\hline diff & & & \\
\hline $\mathrm{Ba}$ & $\ldots$ & $\ldots$ & \\
\hline 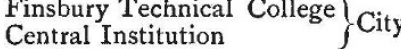 & & & \\
\hline
\end{tabular}

Thus the opening of the greater number of these institutions falls within the decade $1875-1884$.

The benefits arising from the creation of these numerous institutions have not, however, been by any means limited to those persons who have actually taken advantage of their instruction, for their existence has stimulated the establishment of many other institutions, some of which, like the two colleges founded and maintained out of the resources of the City and Guilds of London, although more limited in their scope, afford equal or even greater opportunities for higher scientific training in the particular branches which are represented.

The foundation of these University Colleges and of other institutions for higher education by private initiative, and with-

NO. I 664, vOL. 64] out a particle of assistance from the public exchequer, is quite in keeping with the history of a country in which it is recognised that the Government does not lead, but only follows where it is drawn or propelled.

It would certainly be anticipated that such a large addition to the machinery for higher scientific training as is represented by the creation of these numerous local colleges during the past twenty five years would have had a marked influence on the output of scientific discovery in this country. We will endeavour to ascertain whether such a result is discernible in the case of chemical science. Turning to the Transactions of the Chemical Society, I have compiled the following table in the hope of obtaining some information on this point :-

Original Communications in the Transactions of the Chemical Society.

\begin{tabular}{|c|c|c|c|c|c|c|c|c|c|c|c|}
\hline 1849 & $\cdots$ & 29 & 1862 & $\ldots$ & $8 I$ & I875 & $\cdots$ & 49 & I 888 & $\ldots$ & 75 \\
\hline $185^{\circ}$ & $\ldots$ & 33 & 1863 & $\ldots$ & $5^{I}$ & 1876 & $\ldots$ & 54 & I 889 & $\cdots$ & 71 \\
\hline $185 \mathrm{I}$ & $\ldots$ & 33 & 1864 & $\ldots$ & 54 & 1877 & $\ldots$ & 58 & 1890 & $\ldots$ & 71 \\
\hline 1852 & $\ldots$ & 28 & 1865 & & 49 & 1878 & $\ldots$ & $\sigma_{I}$ & $189 \mathrm{I}$ & $\ldots$ & 95 \\
\hline 1853 & $\ldots$ & 22 & 1866 & $\ldots$ & 47 & 1879 & $\ldots$ & 84 & 1892 & $\ldots$ & 90 \\
\hline 1854 & .. & 23 & 1867 & .. & 49 & 1880 & . & 75 & 1893 & $\ldots$ & 104 \\
\hline 1855 & $\ldots$ & 30 & I 868 & $\ldots$ & 47 & I $88 \mathrm{r}$ & $\ldots$ & 75 & 1894 & $\ldots$ & 83 \\
\hline 1856 & $\ldots$ & 14 & 1869 & $\ldots$ & 37 & 1882 & $\ldots$ & 65 & 1895 & $\ldots$ & 116 \\
\hline 1857 & $\ldots$ & 14 & 1870 & $\ldots$ & $3^{8}$ & 1883 & $\ldots$ & 63 & 1896 & $\ldots$ & 317 \\
\hline $185^{8}$ & $\ldots$ & 30 & 1871 & $\ldots$ & 28 & I 884 & $\ldots$ & 57 & I897 & $\ldots$ & II 4 \\
\hline 1859 & $\ldots$ & $2 \mathrm{I}$ & 1872 & $\ldots$ & 32 & 1885 & $\ldots$ & 85 & 1898 & $\ldots$ & 102 \\
\hline 1860 & $\ldots$ & 25 & 1873 & $\ldots$ & 46 & 1886 & $\ldots$ & 85 & 1899 & $\ldots$ & 120 \\
\hline $186 x$ & $\ldots$ & 32 & 1874 & $\ldots$ & 49 & 1887 & $\cdots$ & 88 & 1900 & $\ldots$ & 127 \\
\hline
\end{tabular}

The activity displayed in chemical research, as measured by the number of original communications to the Chemical Society, is, however, best followed by a consideration of the aggregate number of papers contributed during the three following decades :-

$$
\begin{aligned}
& \text { Decade } \\
& \begin{array}{cccccc}
1855-1864 & \ldots & \ldots & \ldots & \ldots & 352 \\
1865-1874 & \cdots & \cdots & \cdots & \cdots & 422
\end{array} \\
& \begin{array}{llllll}
1865-1874 & \cdots & \cdots & \cdots & \cdots & 422
\end{array} \\
& \begin{array}{llllll}
1875-1884 & \ldots & \ldots & \ldots & \ldots & 641 \\
1885-1894 & \ldots & \ldots & \ldots & \ldots & 847
\end{array}
\end{aligned}
$$

From these figures it is manifest, even without the application of any of those mathematical processes in which modern chemists are becoming so expert, that the most remarkable increase in the number of original investigations is indeed coincident with that decade, $1875^{-1884}$, in which the great majority of the institutions to which I have referred began to throw their prismatic rays of knowledge on many thousands who until then were sitting in shadow or even in darkness.

That these new institutions should have so immediately borne fruit in the manner I have indicated cannot fail to be surprising to those who have been associated with the early years of almost any of these colleges, for when a faithful record of the experiences of their first professors is written the extraordinary obstacles which these pioneers had to encounter, and which in so many cases they successfully overcame, should afford material for a most remarkable, instructive, and even amusing volume. The worthy founders and their executors or trustees appear in general to have supposed that it was only necessary to provide a spacious building, and then appoint a staff of professors who were to do the rest, whilst the necessity of funds for annual upkeep, for libraries, and for assistants was almost overlooked.

It has indeed been learnt by bitter experience that the cost of efficiently maintaining institutions of this most ambitious character is enormously greater than was supposed in this country twenty-five years ago, and that founding a college, far from resembling the inauguration of a remunerative business, is very like entrance into the bond of matrimony, with its attendant annually increasing demand upon the pecuniary resources of the paterfamilias.

It would not indeed be surprising if some of these modern colleges had been long debarred from contributing directly to the progress of scientific investigation in this country, for this was often assuredly considered amongst the least of the many arduous duties imposed upon their first professors. Ascertained capacity to enxich science was in some cases almost a presumptive disqualification for their chairs, or at any rate took a back 
seat beside enthusiasm for evening classes and faith in the efficacy of that mysterious panacea "technical instruction." It is indeed lamentable to think of the valuable years of productive work lost to the country through so much of the energy of these early professors having been sacrificed to these veritable fetishes of our would-be educational reformers.

Notwithstanding the unfavourable conditions under which most of these university colleges had in the first instance to carry on work, it was not long before they showed that they were to become, even during the tenure of office of their first professors, important centres for the prosecution of research-at least as far as chemical science was concerned. Owens College had indeed already led the way in this matter before the period with which I am more especially concerned to-day, for there the first professor of chemistry had pursued his memorable investigations on the organo-metallic compounds, and had, within the first five years after the foundation of the College, enunciated that generalisation which was subsequently extended into the laze of valency ; whilst under his successors, Sir Henry Roscoe, Schorlemmer, Harold Dixon, and Perkin, jun., the Owens College has become perhaps the largest and best equipped school of scientific chemistry in the British Islands.

From the Yorkshire College, Leeds, opened in 1875, there proceeded immediately in rapid succession that whole series of careful investigations relating more especially to specific volume and other physical constants which we associate with its first chemical professor, Thorpe, and his coadjutors.

In the west of England, where the University College of Bristol was opened in 1876 , the chair of chemistry was first occupied by the man who has so recently once more proved to the world that there are discoveries made in these islands which for striking originality and independence are unsurpassed and hardly equalled elsewhere. It was during his tenure of the chair at Bristol that Ramsay, assisted by his able fellow-worker and successor Sidney Young, carried out those important and most laborious investigations on vapour pressure and the therma properties of liquids which not only displayed his extraordinary fertility and resource as an experimenter, but also revealed that exceptional freshness of mind which has enabled him to discern new methods of attacking problems that have already engaged the attention of many able men before him.

Turning from the west of England to the Midlands, where, in 1880 , there was founded, through the private munificence of the late Sir Josiah Mason, a college bearing his name, which, before even attaining its majority, was transformed at the psychological moment, as by the wand of the magician, into the University of Birmingham. The first professor of chemistry at the Mason College, my distinguished predecessor, Tilden, soon made opportunity there to continue those early researches on the terpenes with which his name will always be associated. We find him also further elaborating the important uses as a re agent of nitrosyl chloride, which he had a number of years previously shown how to prepare in a state of purity, and which has played a somewhat similar part in the exploration of the terpene hydrocarbons that phenylhydrazine has done in the elucidation of the sugar-group. In addition to these investigations we find Tilden at Birmingham also turning his attention to some of the phenomena attending the solution of salts. The younger men attached to the Mason College also found there the opportunity of enriching chemical science with the results of notable investigations; for do we not all remember Thoma Turner's valuable contributions to our knowledge of the influence of chemical composition on the physical and mechanical properties of cast iron? Whilst early amongst those detailed investigations on the phenomena of solution, which in recent years have had such far-reaching effects on the development of our science, must be mentioned Dr. Nicol's experiments on the volume changes attending the mixture of salt solutions, and on the molecular volume, the boiling point, and expansion of such solutions.

In the bleak north-east of our island, at Dundee, where a college was founded in 1882 with an extremely handsome en dowment by members of the Baxter family, the first professor of chemistry, Carnelley, fired by that restless and almost perfervid energy which doubtless hastened his untimely end, soon found opportunity to interrogate Nature in various directions, notwithstanding the arduous teaching duties which his insatiable love of work had imposed upon himself. Thus, already in I884, we find him, in his quest for material which should throw light on the periodic relationship of the elements, continuing his laborious work on melting points and publishing those two ponderous quarto volumes in which every known melting point was recorded, and forming truly one of the most remarkable compilations ever attempted in our science. Of these volumes he might indeed have said, " Exegi monumentum ære perennius," for they will assuredly prove a record of the boundless energy which characterised the man, more imperish. able even than the memorial tablet erected by his admiring students and friends in the entrance hall of the Dundee laboratory, which he built and loved so well

Yet another chemist, whose untimely death we have had to lament during the past twenty years, laboured with marked zeal in one of these new colleges, for it was at Aberystwyth that Humpidge, regardless of his delicate health and in spite of the altogether unreasonable burden of teaching duties imposed upon him by the terms of his appointment, contributed to our knowledge of the atomic weight of beryllium, and participated in establishing the position occupied by that metal in the natural classification of the elements.

Time does not permit me to further dilate upon the great activity displayed by many of the first occupants of the chairs of chemistry in these provincial University Colleges. It is also unnecessary for me to do more than remind you of the work accomplished by the two Colleges of the City and Guilds of London, the chemical laboratories of which have from their very inception been under the stimulating influences of Dr. Armstrong and Prof. Meldola, foci of research from which a number of young chemists of distinction have already emanated.

In recent years we have witnessed the genesis of another class of institution, less ambitious in their aspirations than the University Colleges, but indirectly also of much importance in their bearing upon the nurture of scientific chemistry in this country. I refer to the so-called Polytechnics which have sprung up in several parts of the metropolis, and to some other institutions of similar scope in different parts of the country. If research in the University Colleges has been the product of their professors rather than of the environment which they afford, assuredly this is even far more so in the case of these Polytechnics, which are primarily evening schools for the benefit of those who have other occupations during the day. That the young lecturers on chemistry at these places should find time and opportunity for original research, and that sometimes of a very high order, is indeed a brilliant testimonial to their in domitable energy and resourcefulness. Overburdened with large classes until late hours at night, often in those remote and hideous parts of London which suggest to most of us only Slumland and the philanthropic efforts of Toynbee Hall or of Dr. Barnardo, these young chemists awake in the morning only to return as rapidly as possible to those laboratories which exercise on them a fascination as subtle and magnetic as that which draws the commonplace Englishman to the golf-links, the cricket field, or the racecourse. It was in the laboratory of such a technical school, the Heriot Watt College, at Edinburgh, that my distinguished predecessor in this chair, my friend Prof. Perkin, created his opportunities for devising and carrying out those now classical methods of building up carbon ring which are the admiration of all organic chemists throughout the world; methods which he has recently brought to such a pitch of perfection that he is not only able to forge these rings in great variety, but to "bridge" them with links of carbon atoms. It was at the Heriot Watt College also that his work on berberin was performed, and it was here that he contracted that fertile alliance with Dr. Kipping, his able coadjutor in so many valuable investigations.

At the London Polytechnics, again, more recently, we have had similar examples of fertility, for are we not all familiar with the masterly work of Mr. W. J. Pope, who by his investigations at the Goldsmiths' Institute has extended our knowledge of asymmetric atoms, and has shown that optical activity, which hitherto had only been associated with carbon, and somewhat doubtfully with nitrogen. can certainly be produced, not only by asymmetric pentad nitrogen, but also by tetravalent tin and sulphur? Dr. Hewitt, again, whom I am proud to nurnber among my former students, has shown that the laboratory of the People's Palace, Whitechapel, may be made a centre in which abstruse investigations on the aromatic compounds can be carried on.

There is, however, perhaps nothing which testifies morestrongly to the zeal for original investigation amongst British chemists than the manner in which some of the science masters at our schools

NO. I664, VOL. 64$]$ 
have participated in the advancement of chemical knowledge. Some of these schools have, indeed, from time to time secured the services of men whose names are indelibly engraved on the records of scientific chemistry, and it is from the laboratories of these schools that in some cases perhaps their best work has emanated. Of the chemical investigators who have laboured in school laboratories there occur to me, amongst the living, Debus and Clowes at Queenwood, Tilden and Shenstone at Clifton, Purdie at Newcastle-under-Lyme, Brereton Baker at Dulwich, Charles Baker at Shrewsbury. To these names might be added many more ; indeed an examination of the list of Fellows of the Chemical Society shows at what a number of schools throughout the country the chemical teaching is now imparted by men who have themselves advanced the science which they profess.

From the conspicuous instances which I have brought before you - and they might, did time allow, be greatly multiplied-it must be obvious that if a chemist only possesses the necessary enthusiasm and qualifications he will, no matter how inauspicious his surroundings, succeed in doing something to extend the boundaries of his science, and I think I may go further and say without fear of contradiction that in this devotion to research the chemist in this country usually throws into the shade the representatives of other branches of science. How is this preeminent zeal of the British chemist to be explained ? I believe that there are two principal causes in operation which have brought about this result. Firstly, the great majority of the higher chemical teachers in this country have been trained in Germany, or have been trained by men who were themselves trained there; and secondly, they have only in exceptional cases been educated at the ancient seats of learning. Their inspiration and enthusiasm are almost invariably directly or in directly traceable to a German origin, and this fire is kept alive by their remaining in constant touch with German chemical literature.

It is being continually impressed upon us in the newspapers and dinned into our ears from every platform that it is imperative for this country to approximate more to German ideas and methods, and in general to cast away our insular prejudices, obstinacy, and self-satisfaction. We chemists have already done these things; we have emancipated ourselves from the mischievous illusions which have a tendency to thrive in a country enjoying an isolated geographical position. For, during the last half century the academic springs of Germany have been visited by a stream of young English chemists, a stream which, for the perennial regularity of its flow, reminds one indeed of the pilgrimage made by our fashionable invalids to the same country in the hope of correcting the effects of high living by the waters of Homburg, Kissingen, and Wiesbaden. There must indeed be few chemists who return from the German temples of science without bringing back at least a spark of the sacred fire to be kindled on an altar at home; and although at times it may be stifled by the island fog, or burn low through the scarcity of fuel, it generally smoulders long before going out altogether.

The chemist, again, is generally, as I have said, unfettered by an English university record : he stands or falls by the work of his life, and not, as so many others do, by the reputation which they have made in three short years of adolescence at one of the ancient seats of learning.

The spirit of research, which was formerly but a sporadic manifestation within the walls of these venerable institutions, has, however, now become endemic there also, and for a number of years past chemical literature has received a continuous stream of original communications from Oxford and Cambridge, as well as from the Universities of Scotland and Ireland. Instead of those occasional contributions which were customary in the past, we have now evidence that these centres in several case yield to none in the energy and success with which chemical investigation is being pursued, and that the work of the chemical staff is being shared in by advanced pupils trained at these universities themselves. In this connection it is quite unnecessary for me to remind you of the contributions to British Chemistry within recent years by Crum Brown and his pupils at Edinburgh, by Japp at Aberdeen, by Purdie and James Walker at the duplex university now working so harmoniously north and south of the Tay, by Emerson Reynolds at Dublin, and by Harcourt and Harold Dixon, Liveing and Dewar, Ruhemann, Heycock and Neville, Fenton, Sell, Marsh and others, who have brought our science into such living prominence on the banks of the Cam and the Isis.

NO. I 664, voL. 64$]$
It is, however, not at home only that British chemists have displayed their devotion to research, for with the world-wide relations of the empire it has naturally fallen to the lot of some of our number to carry the science to the uttermost parts of the earth, but it is surely a matter of which we may be justly proud that some of these missionaries, like Mallett, Liversidge, Pedler and Rennie, have in these distant lands carried out a number of most important scientific investigations ; whilst to one of them, Dr. Divers, belongs the great distinction, not only of having carried chemistry to the Far East, but of having reared a most active school of chemical research in that fascinating island empire of the rising sun and the chrysanthemum which has won the unfeigned admiration of the West.

The annals of British Chemistry are, however, by no means an exclusive record of the exploits of those engaged in the teaching of our science. I have already referred to the importance of the contributions made by men of leisure, but an equally noteworthy feature of British Chemistry is that its progress has been so often furthered by men who have snatched the time for investigation out of a busy professional or industrial life. Belonging to this category the names of a long line of distinguished chemists of our own time suggest themselves: Warren de la Rue, Hugo Müller, Sir John Lawes, Sir William Crookes, Sir William Abney; Peter Griess, Newlands, O'Sullivan, Horace and Adrian Brown, Harris Morris, Cross, and Bevan. To this group of chemists belongs also Dr. Ludwig Mond, whose technical researches have been of such great value to industrial chemistry, whilst his devotion to the pure science is attested by his interesting discovery and investigation of the metallic carbonyl compounds, and by his conception and munificent endowment of the Davy-Faraday Laboratory, in which such unique opportunities for research have been provided by him.

This would appear to be the most fitting moment also to refer to certain other institutions intended for purposes of research which have been established during the past twenty-five years. Of these the first is the Rothamsted Laboratory, so celebrated during the last half-century for the memorable investigations of Lawes, Gilbert, Pugh, and Warington, but which has more recently, through the generosity of the late Sir John Lawes, been rendered a permanent home for the elucidation of agricultural problems both by laboratory experiments and by trials in the field. Secondly, there is the Research Laboratory which the Pharmaceutical Society has established with the view of raising to a higher level the chemical education of its most promising future members. This laboratory has furnished the opportunity for the valuable investigations of its first director, Prof. Dunstan, and of his successor, Dr. Collie. Still more recently a chemical research laboratory has been established in the Imperial Institute. That noble building has within the last few years undergone a process of transverse subdivision, one-half having assumed an independent existence as the nucleus of that still crystallising body, the University of London; whilst in the remaining half the work of the Institute is now carried on in such silence that we have almost forgotten its existence. For where is the florid music with which on summer nights the air of South Kensington was wont to reverberate? Gone. Gone also are the tea tables, the gardens with their million fairy lights, and the promenading crowds in gay attire. But if the Institute, founded by public subscription to watch over and advance the prosperity of the British dominions, has been impoverished by the discontinuance of these revels, it has become enriched and has gained in dignity by the creation within its walls of a Research Laboratory in which Prof. Dunstan and his assistants are busily investigating the chemical nature of numerous interesting products obtained from all parts of Greater Britain.

There can, in my opinion, be no doubt that this much ex. tended cultivation of scientific chemistry in this country, which is such a noticeable feature of the concluding years of the nineteenth century, has been greatly assisted by a most fortunate, and more or less accidental, circumstance, without which the energy and enthusiasm of our chemical teachers would have been seriously restricted in their influence. I refer to the very substantial surplus, producing an income of $6000 \%$. to $7000 /$. a year, of which the Commissioners of the $185 \mathrm{I}$ Exhibition found them. selves possessed, and its utilisation on the advice of the late Lord Playfair for the purpose of the Research Scholarships which have for some ten years past been so highly prized by all the educational institutions permitted to participate in them. The good wrought by these scholarships has been very far- 
reaching, and it would be difficult to praise too highly the wisdom displayed by the Commissioners in drawing up the conditions on which they are awarded. Firstly, by not limiting them to any one science, they have stimulated a wholesome rivalry between departments to bring on their promising students to the level of scientific investigation. Secondly, they have compelled the governing bodies of educational institutions to recognise and make provision for research as part of the regular programme of these places. Thirdly, they have encouraged talented students to devote an additional year, or even more, to their education in the hope of securing one of these prizes; and these students have thus provided their teachers with the bersonnel necessary for carrying on scientific work. Fourthly, the scholars themselves have had the inestimable advantage of extending their horizon, and of coming in contact with other teachers, other schools of thought, and other views of life. Fifthly, these scholars on their return, and before they have obtained definite employment, are welcomed as supernumeraries in English colleges, where they have an opportunity of continuing their researches, and where they assist in imbuing the students with the spirit which they have themselves imbibed. Lastly, these and other scholarships of a similar character are providing the country with a body of highly trained men whose value to the nation is annually becoming more appreciated, and whose work will continue to bear fruit directly or indirectly for an indefinite period of time. These Exhibition scholarships have now been awarded since 1891 , and already no fewer than sixty-five chemists, including three women, have enjoyed the enormous privilege of extending their education for a period of two, and in special cases even three, years under the most favourable surroundings.

Bearing in mind the rooted objection which pervades the people of this country to expend any public money on higher education, it is marvellous that it should have been possible to employ this fund, which after all is of a quasi-public character, for what may be described as educational use at a high potential, instead of its being dissipated in the manner so dear to Englishmen, by benefiting to an infinitesimal extent a much larger number of persons. Indeed, but for the vertebrate character of the Commissioners in 1877 , the fund would have been thus frittered away, for in that year they were waited upon by a deputation of influential persons who urged that the money should be distributed in grants to provincial museums. Had that been done what would have been the result? The masses would have had a few more glass cases to gaze at on wet days and bank holidays !

There can, I think, be little doubt that in this matter of the allocation of funds intended for the public good we have reached a turning-point in the road which we have been solong pursuing. Until recently it has been the feeling of a very powerful majority in this country that public money should only be spent in such a way as to directly benefit very large numbers; and in the case of educational funds, therefore, it was only their utilisation for the benefit of the masses that could be entertained. Now, whilst it is indubitable that the improvement of our primary education was for many years a crying necessity, it has long been obvious to a minority that this policy is systematically starving that higher education in which we are lagging more and more behind those other countries in which greater elasticity prevails, and in which the immediate and obvious wants of the community receive prompt attention without regard to the traditions and doctrinaire principles of a past generation. In the matter of higher scientific education, at any rate, it is becoming more and more widely recognised that its starvation through attention being exclusively directed to the low-level education of the masses is defeating the very ends which this policy has in view. Indeed, some practical men, and even a few statesmen, realise that the many are beginning to suffer from the results which this policy has had on our manufactures and commerce, without which the multitude can have no existence at all.

The more than princely patronage of higher education by that Scotsman who has not forgotten the land of his birth during fifty years spent in a country which has afforded the necessary scope for his genius and energies illustrates the change in the wind of opinion amongst practical men; for Mr. Andrew Carnegie's handsome contribution to the funds of the University of Birmingham, and his endowment of the Universities of Scotland on a scale which is altogether without precedent, clearly show which, in his opinion, are the rungs in the educational ladder of this country that require strengthening in the interest of those very masses which it is his earnest desire to benefit. The still more recent response of the City Council of Birmingham to Mr. Chamberlain's suggestion that a rate should be levied in aid of the university of that city is further evidence that Mr. Carnegie's practically expressed opinion is shared by the enlightened rulers of that great municipality to which I have the privilege of belonging.

These, ladies and gentlemen, are, I believe, no mere sporadic manifestations, but unquestionably signs of the times. The opening of the new century is in reality a year of very serious awakening to those Englishmen who are not deaf to the voices in the air around them. It is rapidly dawning upon many that "the greatest empire which the world has ever seen" cannot be maintained unless we cast off insular prejudices and traditions, and make a careful study of those points in which other nations are our superiors, with a view to the intelligent adaptation and development, as distinguished from mere imitation, of their methods to our own particular needs.

The survey of the British chemical world at the dawn of the twentieth century affords, however, scope for satisfaction in many ways. Not only have the places in which higher chemical work can be and actually is carried on been greatly multiplied, but the number of workers has been largely increased; and although the enthusiasm of these workers cannot well be greater than that of those who laboured so successfully twenty years and more ago, it has not become diminished, and is certainly diffused more widely amongst the personnel of our colleges and universities. In this connection I need only remind you of the large number of active and independent investigators who are to be found amongst the members of the junior staff at almost every college in the country, and which is altogether without parallel in the past.

There are hardly any of the great problems now exercising the minds of chemists throughout the world which are not being worked at by some of our number; whilst that some chapters in the recent progress of chemical science are more or less specifically British, I would only remind you of the isolated labours of Dr. Perkin in the field of magnetic rotatory power; of Sir William Crookes's exploration of the phenomena occurring in high vacua; of the researches of Abney, Russell, and Hartley on the absorption spectra of organic compounds; of the investigations by Harold Dixon and Brereton Baker of the behaviour of substances in the complete absence of moisture; of the extension by Pope and Smiles of our knowledge of asymmetric atoms; of the near approach to the absolute zero of temperature by Dewar; and of those marvellous discoveries of Raleigh and Ramsay which have not only introduced us to five new aërial elements, but have revealed the existence of a hitherto unknown type of matter, which is apparently incapable of entering into chemical combination at all.

But whilst we may thus congratulate ourselves on this increased activity in chemical investigation, and upon the main tenance of a high standard of quality by the exceptional brilliancy of the researches of some of our number, we must now carefully consider how we stand with regard to the absolute quantity of our output.

I have called your attention to the evidence of activity in the British chemical world which is furnished by the number of original investigations communicated to the Chemical Society of London. Let me now ask you to turn to the corresponding picture, which is furnished by the statistics of the much younger Chemical Society of Berlin.

\section{Original Communications to the Chemical Society of Berlin.}

\begin{tabular}{rrrrrr|rlr|rrr}
1868 & $\ldots$ & 97 & 1877 & $\ldots$ & 568 & 1886 & $\ldots$ & 696 & 1895 & $\ldots$ & 636 \\
1869 & $\ldots$ & 252 & 1878 & $\ldots$ & 602 & 1887 & $\ldots$ & 708 & 1896 & $\ldots$ & 566 \\
1870 & $\ldots$ & 277 & 1879 & $\ldots$ & 604 & 1888 & $\ldots$ & 658 & 1897 & $\ldots$ & 560 \\
1871 & $\ldots$ & 288 & 1880 & $\ldots$ & 563 & 1889 & $\ldots$ & 601 & 1898 & $\ldots$ & 555 \\
1872 & $\ldots$ & 303 & .1881 & $\ldots$ & 495 & 1890 & $\ldots$ & 630 & 1899 & $\ldots$ & 549 \\
1873 & $\ldots$ & 420 & 1882 & $\ldots$ & 541 & 1891 & $\ldots$ & 677 & 1900 & $\ldots$ & 636 \\
1874 & $\ldots$ & 516 & 1883 & $\ldots$ & 535 & 1892 & $\ldots$ & 553 & & & \\
1875 & $\ldots$ & 488 & 1884 & $\ldots$ & 646 & 1893 & $\ldots$ & 587 & & & \\
1876 & $\ldots$ & 517 & 1885 & $\ldots$ & 686 & 1894 & $\ldots$ & 653 & & &
\end{tabular}

A comparison between these figures and those of the London Chemical Society shows that chemical science occupies an entirely different place in Germany from that which it even now does in this country.

NO. I 664, VOL. 64] 
Is this state of affairs to continue throughout the twentieth century? Are intellectual ambitions to be for ever subordinated to the extension of territory, to the acquisition of that metal which has had its atomic weight so accurately determined by Thorpe and Laurie, and to those other problems which fill the political horizon? Even the most recent awakening of interest in higher scientific education is not altogether of the breed to satisfy us as men of science; for the interest is assuredly not in the pursuit of knowledge for its own sake, but is aroused by the desire to secure those material advantages which it is beginning to be realised must inevitably result from the steadfast prosecution of scientific research. This is indeed a very different spirit from that which has led to the proud position occupied by science and learning of all kinds in Germany.

Schiller has truly said-

"Knowledge is to one a goddess, to another only an excellent cow."

I fear there can be no doubt that here it is the cow, and not the goddess, that is in request. Thus, whilst in Germany the love and reverence for knowledge preceded the esteem of knowledge for the material benefits which it confers, we must hope that in our country the eagerness to secure the material advantages will perhaps lead to a love and reverence for that which confers them, so that in the course of time, perhaps, the useful cow will be allotted a stall on Olympus, or be at least pastured on the grass of Parnassus.

From whatever motive, whether utilitarian or otherwise, we wish to see the position of science in this country raised, and the qualitative and quantitative output of scientific work increased, I imagine that the methods to be immediately pursued for attaining this end must be very similar.

If the higher teaching of science is to be really encouraged the first necessity is that this higher teaching shall offer a sufficiently attractive career to the man of ambition as well as to the enthusiast. We all know that the supply of enthusiasts of intellectual power combined with capacity to perform is extremely limited and wholly inadequate for carrying out the important work of the world, and that the greater part of such work is actually done by men of ambition.

In order that the academic world may attract the ablest men of ambition as well as that rara avis, the able enthusiast, it is necessary that the highest prizes for academic distinction should carry similar social prestige, similar remuneration, and similar opportunities of exerting public influence as are enjoyed by the leaders of other professional callings : they should be at least equal to those of the Archbishop of Canterbury or of the Lord Chancellor. It is not by any means necessary that such prizes should be numerous, as is abundantly demonstrated by the volume of able ambition which is drawn into the Church and to the Bar by the comparatively few opportunities for great success in those professions. The enthusiasts already find their way into the academic world, and, although they maintain the quality of British scientific work, they are unable, by virtue of their scarcity, to maintain the quantity which is essential for the luxuriant growth of science in our midst, whilst the absence of such tangible rewards as are bestowed in other spheres of intellectual activity prevent the importance of science being recognised by a public which has no appreciation of the inward and spiritual grace unless guided by the outward and visible sign.

Precisely the opposite policy, so far as remuneration is concerned, has, however, been pursued in the academic world during recent years, the few very moderate prizes which formerly existed having been deliberately commandeered to more nearly equalise the value of the chairs in all departments.

The principle of equalising the remuneration of different chairs is as inequitable as it is utterly unsound from a business point of view. The principle is unsound because equal salaries will not secure men of similar standing in different subjects : it is inequitable because the amount of work attaching to the chairs of different subjects is necessarily very unequal, as is the order of intellect required for the successful discharge of their duties.

Again, the system which is gaining ground in this country of allocating a certain stipend to a chair is unbusinesslike and mischievous. It is as irrational to fix the remuneration of a particular chair as it would be to fix the price to be paid for one's portrait, irrespectively of whether it were taken by a photographer or painted by a Royal Academician. If we really want the best man for any particular professional service, whether it be to treat us for a disease, to plead our cause in a court of law, or to perform on some musical instrument for our delectation, we know that we must make up our minds to pay the price which the best man commands in his particular profession, and it is absurd to suppose that the same principle does not hold good in the matter of securing the best man for an academic appointment. This, again, is intimately connected with the desirability of providing a sufficient number of steps in the academic ladder, so that it shall not be possible for the "young man of promise" to be rushed into a first-class appointment from which he has no ambition to move for the remainder of his days.

Another matter, again, requires consideration: if we are really in earnest in the attempt to bring our universities abreast of those in other countries, our chairs must be systematically thrown open to the whole world, and the best men obtainable secured, irrespectively of their nationality. Not only have small nations adopted this plan, but even the nation which is preeminent for its academic strength is by no means blind to the importance of drawing into its service from the outside men of commanding brilliance and power. I need not remind you that England has also exhibited a wise and liberal spirit in this matter in the past, and that, so far as our science is concerned, this policy has been most fully justified. For, consider only what the English Chemistry of the latter half of the nineteenth century owes to the genius and magnetic influence of the im. ported Hofmann. I can imagine the electors to British chairs suggesting that there might be linguistic difficulties in the way of carrying out such a policy, in answer to which I would appeal to the pupils of Hofmann to say whether his stimulating discourse lost anything of its vigour and inspiration through the strong Hessian accent with which every word of it was saturated. It is to be hoped that no narrow and short-sighted policy, disguised under that too often misused word "patriotism," will seek to close the doors of our universities to the genius and ability of other nationalities.

I believe, however, that one of the most urgent and pressing of University reforms is that greater facilities should be afforded for the migration of students from one university to another, without prejudice to their acquisition of a degree. It is the present system, which practically chains an undergraduate with links of steel to the university at which he matriculates, that is at the root of many of the evils under which our higher education is labouring.

The university at which a youth matriculates is often determined by the fatuous, although pathetic, wish of the father that his son should spend his time, I will not say work, amidst the surroundings which awaken such pleasant memories in himself ; and the youth once within the magic portals has little or no opportunity of rectifying the possible mistake of his fond parent, who has probably for a quarter of a century been quite out of touch with university matters, or even divorced from the intel. lectual world altogether.

This foolish sentiment of loyalty to a university or even college is sometimes kept up for generations, and I have met persons who have told me that their family had always been Balliol or Trinity men, with the same sort of pride that they would doubtless have informed me, had they been able, that their ancestors came over with the Conqueror or had charged with the Cavaliers at Naseby.

The prevalence of such a sentiment shows that our universities are principally valued for their social attractions, as well as for their past history and ancient traditions, in which connection it is always well to remember that a living dog is better than a dead lion.

The possibility of students dissociating themselves from the university of their matriculation and freely migrating from one school to another would, in my opinion, not only be of immense advantage to the students themselves, enabling them to obtain the best instruction in each particular subject and greatly extending their horizon and knowledge of the world, but it would operate most favourably on the universities themselves, minimising the tendency to stagnation, and compelling those who hold the purse-strings to provide for the strengthening of weak departments. Nor should the possibilities of migration be limited to the Universities of the United Kingdom or even of the British Empire, but the prospect should be kept in view of ultimately effecting an arrangement whereby students could enjoy the advan. tage of visiting the universities of other countries.

Such migration is, of course, closely connected with the duration of the period of university study, and in this matter reform is most urgently needed. The traditional three years devoted to the acquisition of a degree is hopelessly inadequate

NO. I 664 , vOL. 64$]$ 
for the higher purposes of university training, especially when the very immature age at which English students generally begin their university career is taken into consideration. The period of academic study should be forthwith extended to five years, as it is only in this way that the university can be effectively made a centre of research. Without a course of study of such duration, and of which research forms a part, it is quite impossible that the highly trained men who are now so urgently needed for practical avocations should be produced.

In this connection, again, we all know that much mischief has been going on in recent years. Instead of the terms on which degrees are at present obtainable being regarded as too lenient and easy, proposals are actually being put forward in some quarters to enable persons attending evening classes to thereby qualify for university degrees. Now, whilst it is of the utmost importance to provide abundant opportunities for the talented poor to obtain a university education by reducing the fees and by instituting a sufficient number of bursaries, it is imperative that those who are to be stamped with the distinctive mark of a university should have devoted their whole and undivided attention, over a certain period of time, to the courses of study prescribed. Let us beware of introducing the halftime system into the university, a system which we know to be a deplorable makeshift even in the elementary school.

In this matter of the aspirations, scope and functions of a university we have not merely to contend with the ignorance and apathy of the average Philistine, but we are wrestling against principalities, against powers and against darkness in high places. Thus only four months ago one of our most prominent statesmen, whose oracular and sporadic utterances inspire amongst millions almost the awe and respect which is felt for the supernatural, is reported in the columns of the daily papers to have said at one of the most important educational gatherings of this first year of the new century:- "You, Mr. Vice-Chancellor, spoke of the stigma that would rest on the University if it did not annually produce some work of original research. I, from another point of view, am contented if you do nothing of the kind. I am satisfied to think that in a large and increasing degree you will train men and women fit for the manifold requirements of this Empire." This statesman, who it is not surprising to find was educated at Eton and Oxford, is thus of the opinion to-day, unless, indeed, his views have changed in the interim, that it is possible to train men and women fit for the manifold requirements of this Empire without bringing, at any rate, some of them into contact with the living spirit of research-that spirit which, operating through the ages, has enabled man to transform the wilderness in which he was placed by his Creator into the garden of material and intellectual enjoyments in which that statesman was himself born.

I would ask you to contrast with the views of the distinguished alumnus of Eton and Oxford the utterance of another statesman who, unhampered by such educational antecedents, has formulated the following ideal for the guidance of that university which he has himself created :-

"The third feature to which I should call attention, and which, I am inclined to say, is of all the most important, is that a university should be a place where knowledge is increased, and where the limits of learning are extended. Original research, the addition of something to the total sum of human knowledge, must always be an essential part of our proposals."

Lastly, we have to consider whether this university work, in which we hope for such great developments in the twentieth century, is still to be carried on by what is virtually private enterprise and private endowment, or whether it is to be provided for by taxation.

If the reforms and developments which are being preached from so many platforms are to be really carried out, if even our higher scientific training alone is to be brought into line with that which is provided in many other countries, it is indubitable that expenditure will have to be enormously increased. Now, profoundly as we all admire the enlightened public spirit of the men and women who have in the past endeavoured out of their private resources to help forward the great movement of higher education, it is, I believe, the firm conviction of all who have any real knowledge of what this higher education means, and a clear conception of what must be done in order to put it on a proper footing in this country, that on private benefaction alone this work cannot be accomplished. But even if private endowment could raise this great $\epsilon$ bfice in our midst, it is obvious that we should have to wait indefinitely for its realisation. Voluntary contributions cannot be made to come at the bidding of those who stand in need, nor directed into the channels where they will produce the most good; they have to be patiently waited for, with the result that valuable time is lost and opportunities pass by never to return. Private benefaction, moreover, is almost always retrospective : a hospital is not founded by the charitable until the sick are dying unattended; almshouses and orphanages are not thought of until the widow and the fatherless are either starving in the streets or begging on the doorstep. What we so forcibly recognise in this matter, however, is that we have not only to make up for leeway in the past, but that we must now exercise prevision to prevent similar disastrous lapses in the future. The state of affairs to which we have been reduced must not be allowed to occur again ; the warnings of those possessing special knowledge in these matters must not be disregarded in the future as they have been in the past, for it is no exaggeration that the whole of the learned societies and academic bodies of this country put together have at present a smaller corporate share of political influence than a Temperance League or a Trades Union. To what has this state of things reduced us? The humiliating spectacle of "the greatest empire the world has ever seen" at the beginning of the twentieth century without a teaching university in its metropolis, and engaged upon the task of tardily patching one together out of those heterogeneous elements. of uncertain valency which are to hand. Is the completion of this structure, on a scale challenging comparison with the universities which are to be found in the other great capitals of Europe, to be delayed until a millionaire, or rather series of millionaires, can be induced to finance it? To this work, and to other works like it, is it not fitting that every inhabitant of this country should contribute? For these are works which assuredly benefit all classes, not only of this generation, but of those which are to come-at least as much as the acquisition of territory at a distance of 8000 miles from home, and for which purpose the nation is apparently willing to pay at the rate of one and a quarter million sterling per week for an indefinite period of time.

It is sometimes urged that this higher education does not benefit the masses ; but could any contention be more erroneous? The poor have really a far greater stake in the prosperity of our home industries and commerce than the rich; for whilst the decay of our producing power will remove the very means of subsistence from the poor, it matters very little to many of the rich whether their dividends are derived from home-enterprises or from those of a Billion Dollar Combine or some similar transatlantic Trust or Corporation.

Higher education and true universities are also amongst the most potent factors in breaking down the hereditary stratification of society and in minimising the advantages depending upon the accident of birth, so that, with the greatly enhanced facilities which must be provided for students without means, they should afford in the future, even more than they have done in the past, an avenue for the humblest boy of talent to that position which he is by natural endowment and by his own exertion best fitted to fill in the interests of the State.

Is this great work of raising up a worthy system of national higher education, and of creating a living interest and widely diffused enthusiasm for knowledge and for the increase of knowledge in all its branches, going to be accomplished during the century of which we have but crossed the threshold? Even the most sanguine among us dare not unhesitatingly say Yes; but assuredly upon the answer, which is hidden by the veil of the inscrutable future, depends in the very highest degree, not only the material and intellectual welfare of the rising generations, but also the good name and reputation of the Empire in our own time and the gratitude which, above all things, we should strive to earn from that immortal part of us which we call Posterity.

\section{SECTION C.} GEOLOGY.

OPENING ADDRESS BY JOHN HORNE, F.R.S., F.R.S.E., F.G.S., Presiden't OF THE Sectron.

Recent Advances in Scottish Geology.

A QUARTER of a century has elapsed since the British Association met in this great industrial centre, when Prof. Young, in his presidential address to this Section, pointed out some of the difficulties which, as a teacher, he experienced in summarising

NO. I 664, VOL, 64] 
the principles of geology for his students. At that meeting, also, the late Duke of Argyll. whose interest in geological questions never faded, gave an address " On the Physical Structure of the Highlands in connection with their Geological History." The return of the Association to the second city of the empire, which since 1876 has undergone remarkable development, due in no small measure to the mineral wealth of the surrounding district, suggests the question, Has Scottish geology made important advances during this interval of time? Have we now more definite knowledge of the geological systems represented in Scotland, of their structural relations, of the principles of mountain-building, of the zonal distribution of organic remains, of the volcanic, plutonic, and metamorphic rocks so largely developed within its borders? It is true that many problems still await solution, but anyone acquainted with the history of geological research must answer these questions without hesitation in the affirmative. In the three great divisions of geological investigation-in stratigraphical geology, in palæontology, in petrology - the progress has indeed been remarkable. The details of these researches are doubtless familiar to many who have taken an active share in the work, but it may serve a useful purpose, and perhaps be helpful as a landmark to give now an outline of some of the permanent advances in the solid geology of Scotland during the last quarter of a century.

The belt of Archæan gneisses and schists, which may be said to form the foundation stones of Scotland, have been mapped in great detail by the Geological Survey since 1883 along the western part of the mainland in the counties of Sutherland and Ross. In that region they occupy a well-defined position, being demonstrably older than the great sedimentary formation of Torridon Sandstone and overlying Cambrian strata. The mapping of this belt by the survey staff and the detailed study of the rocks both in the field and with the microscope by Mr. Teall have revealed the complexity of the structural relations of these crystalline masses, and have likewise thrown considerable light on their history. These researches indicate that, in the North. west Highlands, the Lewisian (Archæean) gneiss may be resolved into (I) a fundamental complex, composed mainly of gneisses that have affinities with plutonic igneous products, and to a limited extent of crystalline schists which may without doubt be regarded as of sedimentary origin; (2) a great series of igneous rocks intrusive in the fundamental complex in the form of dykes and sills. ${ }^{1}$

The rocks of the fundamental complex which have affinities with plutonic igneous products occupy the greater part of the tract between Cape Wrath and Skye. Mr. Teall has shown that they are essentially composed of minerals that enter into the composition of peridotites, gabbros, diorites, and granites; as, for example, olivine, hypersthene, augite (including diallage), hornblende, biotite, plagioclase, orthoclase, microcline, and quartz. In 1894 he advanced a classification of these rocks, based mainly on their mineralogical composition and partly on their structure, which has the great merit of being clear, comprehensive, and independent of theoretical views as to the history of the rock masses. Stated broadly, the principle forming the basis of classification of three of the groups is the nature of the dominant ferro-magnesian constituent, viz., pyroxene, hornblende, or biotite, while the members of the fourth group are composed of ferro-magnesian minerals without felspar or quartz ("Annual Report of the Geological Survey for 1894," p. 280). The detailed mapping of the region has shown that these rockgroups have a more or less definite geographical distribution. Hence the belt of Lewisian gneiss has been divided into three districts; the first extending from Cape Wrath to Loch Laxford ; the second, from near Scourie to beyond Lochinver, and the third from Gruinard Bay to the island of Raasay. In the central area (Scourie to Lochinver) pyroxene gneisses and ultrabasic rocks (pyroxenites and hornblendites) are specially developed, while the granular hornblende rocks (hornblende gneiss proper) and the biotite gneisses are characteristic of the northern and southern tracts. These are the facts, whatever theory he adopted to explain them.

In those areas where the original structures of the Lewisian gneiss have not been effaced by later mechanical stresses it is possible to trace knots, bands, and lenticles of unfoliated,

1 Report on the Recent Work of the Geological Survey in the North-west Highlands of Scotland based on the Field-notes and Maps of Messrs. B. N. Peach, J. Horne, W. Gunn, C. T. Clough, L. W. Hinxman, and H. M. the Geological Survey for $1894, "$ p. 280 , and 1895, p. 17 . ultrabasic, and basic rocks to note the imperfect separation of the ferro-magnesian from the quartzo-felspathic constituents, to observe the gradual development of mineral banding and the net-like ramification of acid veins in the massive gneisses. Many of these rocks cannot be appropriately described as gneiss. Indeed, Mr. Teall has called attention to the close analogy between these structures and those of plutonic masses of younger date.

In the Report on Survey Work in the North-west Highlands, published in $\mathrm{I} 888$, the parallel banding, or first foliation, as it was then termed, of these original gneisses was ascribed to mechanical movement (Quart. Journ. Geol. Soc., vol. xliv. p. 400). But the paper on "Banded Structure of Tertiary Gabbros in Skye," by Sir A. Geikie and Mr. Teall (ibid., vol. 1. p. 645), throws fresh light on this question. In that region the gabbro displays the alternation of acid and basic folia, the crumpling and folding of the bands like the massive gneisses of the Lewisian complex. Obviously in the Skye gabbro the structures cannot be due to subsequent earth movements and deformation. The authors maintain that they are original structures of the molten magma, and, consequently, that much of the mineral banding of the Lewisian gneisses, as distinguished from foliation, may be due to the conditions under which the igneous magma was erupted and consolidated. Whatever theory be adopted to explain the original mineral banding of the Lewisian gneisses, it is certain that they possessed this banding, and were thrown into gentle folds before the uprise of the latter intrusive dykes.

The crystalline schists that have affinities with rocks of sedimentary origin occupy limited areas north of Loch Maree and near Gairloch. The prominent members of this series are quartz schists, mica schists, graphitic schists, limestones and dolomites with tremolite, garnet and epidote ("Annual Report of the Geo. logical Survey for 1895," p. 17). They are there associated with a massive sill of epidiorite and hornblende schist. The relations which these altered sediments bear to the gneisses that have affinities with plutonic igneous products have not been satisfactorily determined. But the detailed mapping has proved that north of Loch Maree they rest on a platform of Lewisian gneiss, and'are visibly overlain by gneiss with basic dykes (Meall Riabhach), and that both the gneiss complex and altered sediments have been affected by a common system of folds. In the field, bands of mylonised rock have been traced near the base of the overlying cake of gneiss, and the microscopic examination of the latter by Mr. Teall has revealed cataclastic structures due to dynamic movement. It is obvious, therefore, that, whatever may have been the original relations of the altered sediments to the gneiss complex, these have been obscured by subsequent earth-stresses.

The great series of later igneous rocks which pierce the fundamental complex in the form of dykes and sills is one of the remarkable features in the history of the Lewisian gneiss. In I895 Mr. Teall advanced a classification of them (ibid., p. I8), but his recent researches show that they are of a much more varied character. For our present purpose we may omit the dykes of peculiar composition and refer to the dominant types. These comprise: (I) ultrabasic rocks (peridotite), (2) basic (dolerite and epidiorite), and (3) acid (granite and pegmatite). The evidence in the field points to the conclusion that the ultrabasic rocks cut the basic, and that the granite dykes were intruded into the gneisses after the eruption of the basis dykes. The greater number of these dykes consists of basic materials. It is important to note that the basic rocks best preserve their normal dyke-like features in the central tract between Scourie and Lochinver, where they traverse the pyroxene gneisses. But southwards and northwards of that tract, in districts where they have been subjected to great dynamic movement, they appear as bands of hornblende-schist, which are difficult to separate from the fundamental complex. The acid intrusions are largely developed in the northern tract between Laxford and Durness indeed, at certain localities in that region the massive and foliated granite and pegmatite are as conspicuous as the biotite gneisses and hornblende gneisses with which they are associated.

After the eruption of the various intrusive dykes the whole area was subjected to enormous terrestrial stresses which pro. foundly affected the fundamental complex and the dykes which traverse it. These lines of movement traverse the Lewisian plateau in various directions, producing planes of disruption, molecular rearrangement of the minerals and the development of foliation. It seems to be a general law that the new planes

No. I 664, vOL. 64] 
of foliation both in the gneiss and dykes are more or less paraliel with the planes of movement or disruption. If the latter be vertical or nearly horizontal the inclination of the foliation planes is found to vary accordingly.

Close to the well-defined disruption-planes, like those between Scourie and Kylesku, the gneiss loses its low angle, is thrown into sharp folds, the axes of which are parallel with the planes of movement. The folia are attenuated, there is a molecular rearrangement of the minerals, and the resultant rock is a granulitic gneiss. Indeed, the evidence in the field, which has been confirmed by the microscopic examination of the rocks by $\mathrm{Mr}$. Teall, seems to show that granulitic biotite and hornblende gneisses are characteristic of the zones of secondary shear. A further result of these earth-stresses is the plication of the original gneisses in sharp folds, trending N.W. and S.E. and E. and W.; and the partial or complete recrystallisation of the rocks along the old planes of mineral banding.

In like manner, when the basic dykes are obliquely traversed by lines of disruption, they are deflected, attenuated, and within the shear zones appear frequently as phacoidal masses amid the reconstructed gneiss. These phenomena are accompanied by the recrystallisation of the rock and its metamorphosis into hornblende schist. Similar results are observable when the lines of movement are parallel with the course of the dykes. All the stages of change from the massive to the schistose rock can be traced-the replacement of pyroxene by hornblende, the conversion of the felspar and the development of granulitic structure with foliation. Here we have an example of the phenomena developed on a larger scale by the post-Cambrian movements, viz., the production of common planes of schistosity in rocks separated by a vast interval of time, quite irrespective of their original relations. For both gneiss and dykes have common planes of foliation, resulting from earth-stresses in pre-Torridonian time.

It is important to note also that linear foliation is developed in the basic dykes where there has been differential movement of the constituents in folded areas. In the case of the anticline mapped by Mr. Clough, near Poolewe in Ross-shire, he has shown that the linear foliation is parallel with the pitch of the folds. All these phenomena tend to confirm the conclusions arrived at by Mr. Teall, and published in his well-known paper, "On the Metamorphosis of Dolerite into Hornblende Schist" (Quart. Journ. Geol. Soc., vol. xli. p. 133).

The ultrabasic and acid rocks likewise occur in the schistose form, for the peridotites pass into talcose schists and the granite becomes gneissose.

In connection with the development of schistosity in these later intrusive rocks it is interesting to observe that where the basic dykes merge completely into hornblende schist, and seem to become an integral part of the fundamental complex, biotite gneisses and granular hornblende gneisses prevail. Whatever be the explanation, the relationship is suggestive.

The unconformability between the Lewisian gneiss and the overlying Torridon Sandstone, which was noted by Macculloch and confirmed by later observers, must represent a vast lapse of time. When tracing this base-line southwards through the counties of Sutherland and Ross, striking evidence was obtained by the Geological Survey of the denudation of that old land surface. In the mountainous region between Loch Maree and Loch Broom it has been carved into a series of deep narrow valleys with mountains rising to a height of 2000 feet. In that region it is possible to trace the orientation of that buried mountain chain and the direction of some of the old river courses. This remnant of Archæan topography must be regarded as one of the remarkable features of that interesting region.

In 1893 the various divisions of the Torridon Sandstone, as developed between Cape Wrath and Skye, were tabulated by the Geological Survey, which may here be briefly summarised. They form three groups : a lower, composed of epidotic grits and conglomerates, dark and grey shales with calcareous bands, red sandstones, and grits ; a middle, consisting of a great succession of false-bedded grits and sandstones; an upper, comprising chocolate-coloured sandstones, micaceous flags with dark shales and calcareous bands. The total thickness of this great pile of sedimentary deposits must be upwards of 10,000 feet, and if Mr. Clough's estimate of the development of the lower group in Skye be correct, this amount must be considerably increased. Of special interest is the evidence bearing on the stratigraphical variation of the Torridon Sandstone when traced southwards across the counties of Sutherland and Ross. The lower group is not represented in the northern area, but south. wards, in Ross-shire, it appears, and between Loch Maree and Sleat varies from 500 to several thousand feet in thickness. These divisions of the Torridon Sandstone are of importance in view of the correlation of certain sediments in Islay with the middle and lower Torridonian groups which there rest unconformably on a platform of Lewisian gneiss.

In continuation of the researches of Dr. Hicks, published in his paper "On pre-Cambrian Rocks occurring as Fragments in the Cambrian Conglomerates in Britain" (Geol. Mag., 1890, p. 516), Mr. Teall has specially investigated the pebbles found in the Torridon Sandstone. The local basement breccias of that formation have doubtless been derived from the platform of Lewisian gneiss on which they rest, but the pebbles found in the coarse arkose tell a different story ("Annual Report of the Geological Survey for 1895," p. 20). He has found that they comprise quartzites showing contact alteration, black and yellow cherts, jaspers with spherulitic structures which indicate that they have been formed by the silification of liparites of the "Lea-rock" type and spherulitic felsites that bear a striking resemblance to those of Uriconian age in Shropshire. These interesting relics have been derived from formations which do not now occur anywhere in the western part of the counties of Sutherland and Ross, and they furnish impressive testimony of the denudation of the Archran plateau in pre-Torridonian time.

These Torridonian sediments, like the sandstones of younger date, contain lines of heavy minerals, such as magnetite, ilmenite, zircon, and rutile ("Annual Report of the Geological Survey for 1893 ," p. 263). The dominant felspar of the arkose group is microcline, that of the basal group oligoclase. In the calcareous sediments of the upper and lower groups fossils might naturally be expected, but the search so far has not been very successful. Certain phosphatic nodules have been found in dark micaceous shales of the upper group which have been examined by Mr. Teall. From their chemical composition these nodules might be regarded as of organic origin; but he has found that they contain spherical cells with brown-coloured fibres, which appear to be débris of organisms (ibid., 1899, p. I85).

Early in last century the Torridonian deposits were referred by Macculloch (Trans. Geol. Soc., ser. I, vol. ii. p. 450; "The Western Isles of Scotland," vol. ii. p. 89) and Hay Cunningham (Transactions of the Highland and Agricultural Society of Scotland, vol. xiii. I839) to the "Primary Red Sandstone," and by Murchison (Trans. Geol. Soc., ser. 2, vol. iii. p. 155), Sedgwick, and Hugh Miller to the Old Red Sandstone. The structural relations of the Torridon Sandstone to the overlying series of quartzites and limestones were first clearly shown by Prof. Nicol (Quart. Journ. Geol. Soc., vol. xiii. p. I7), who traced the unconformability that separates them for Ioo miles across the counties of Sutherland and Ross. When Salter pointed out the Silurian facies of the fossils found in the Durness limestone by Mr. Charles Peach, the Torridonian formation was correlated with the Cambrian rocks of Wales by Murchison (ibid., vol. xv. p. 353). The discovery of the Olenellus fauna, indicating the lowest division of the Cambrian system, in the quartzite-limestone series by the Geological Survey in I891 (ibid., vol. xlviii. p. 227) demonstrated the pre-Cambrian age of the Torridon Sandstone. In view of that discovery, which proves the great antiquity $o$. the Torridonian sediments, it is impossible to climb those picturesque mountains in Assynt or Applecross without being impressed with the unaltered character of these deposits. Yet it can be shown that under the influence of post-Cambrian movements they approach the type of crystalline schists.

Before proceeding to the consideration of the Durness series of quartzites and limestones and their relations to the Eastern Schists, brief reference must be made to the controversy between Murchison and Nicol regarding the sequence of the strata.

The detailed mapping of the belt between Eriboll and Skye by the Geological Survey has completely confirmed Nicol's conclusions (I) that the limestone is the highest member of the Durness series; (2) that the so-called "Upper Quartzite" and "Upper Limestone" of Murchison's sections are merely the repetition of the lower quartzite and limestone due to faults or folds; (3) that there is no conformable sequence from the quartzites and limestones into the overlying schists and gneiss; (4) that the line of junction is a line of fault indicated by proofs of fracture and contortion of the strata. It is true that

NO. I 664 , VOL. 64$]$ 
in the course of his investigations Nicol's views underwent a process of evolution, and that even in the form in which he ultimately presented them he did not grasp the whole truth. We now know that he was in error when he regarded portions of the Archæan gneiss, occurring in the displaced masses, as igneous rocks intruded during the earth-movements, and that he failed to realise the evidence bearing on dynamic metamorphism resulting from these movements. But I do not doubt that the verdict of the impartial historian will be that Nicol displayed the qualities of a great stratigraphist in grap pling with the tectonics of one of the most complicated mountain chains in Europe.

The perind now under review embraces the reopening of that controversy in 1878 by Dr. Hicks, and its close in 1884 after the publication of the "Report on the Geology of the Northwest of Sutherland," by the Geological Survey (NATURE, vol. xxxi. p. 29, November I884). The Survey work has confirmed Prof. Bonney's identification of the Lewisian gneiss and Torridon Sandstone in Glen Logan, Kinlochewe (Quart. Journ. Geol. Soc., vol. xxxvi. p. 93), brought into that position by a reversed fault; and Dr. Callaway's conclusions regarding overthrust faulting at Loch Broom, in Assynt and in Glencoul (ibid., vol. xxxix. p. 416). Special reference must be made to the remarkable series of papers by Prof. Lapworth on "The Secret of the Highlands," in which he demonstrated the accuracy of Nicol's main conclusions, and pointed out that the stratigraphical phenomena are but the counterpart of those in the Alps, as described by Heim (Geol. Mag., December 2, vol. x. pp. I2O, 193, 337). His researches, moreover, led him to a departure from Prof. Nicol's views regarding the age, composition, and mode of formation of the Eastern Schists, for in the paper which he communicated to the Geologists' Association in I884 he announced that their present foliated and mineralogical characters had been developed by the crust-movements which operated in that region since the time of the Durness quartzites and limestones (Proc. Geol. Assoc., vol. viii. p. 438; Geol. Mag., December 3, vol. ii. 1885, p. 97). Allusion must be made also to his great paper " On the Discovery of the Olenellus Fauna in the Lower Cambrian Rocks of Britain," in which he not only chronicled the finding of this fauna at the top of the basal quartzite in Shropshire, but suggested the correlation of the Durness quartzites and limestones with the Cambrian rocks elsewhere (Geol. Mag., December 3, vol. v. pp. 484-487). That suggestion was strikingly confirmed within three years afterwards by the discovery of the Olenellus fauna in Ross-shire.

The detailed mapping of the belt of Cambrian strata has proved the striking uniformity of the rock sequence. There is little variation in the lithological characters or thicknesses of the various zones. Rasal quartzites, pipe-rock, Fucoid-beds, Serpulite (Salterella) grit, limestone, and dolomite form the invariable sequence, for a distance of a hundred miles, to the west of the line of earth-movements. This feature is also characteristic of the fossiliferous zones, for the sub-zones of the pipe-rock, the Olenellus fauna in the Fucoid-beds, and the Salterella limestone have been traced from Eriboll to Skye. Owing to the interruption of the sequence by reversed faults or thrusts, the higher fossiliferous limestone zones are never met with between Eriboll and Kishorn, but they occur in Skye, where they were first detected by Sir A. Geikie (Quart. Journ. Geol. Soc. vol. xliv. p. 62).

Regarding the palæontological divisions of the system, my colleague, Mr. Peach, concludes "that the presence of three species of Olenellus in the Fucoid-beds and Serpulite-grit of the North-west Highlands, nearly allied to the American form Olenellus Thomsoni-the type species of the genus-together with Hyolithes, Salterella, and other organisms found with it, prove that these beds represent the Georgian terrane of America, which, as shown by Walcott, underlies the Paradox ides zone." Hence he infers that there can be no doubt of the Lower Cambrian age of the beds yielding the Olenellus fauna in the North-west Highlands. Mr. Peach further confirms Salter's opinion as to the American facies of the fossils obtained from the higher fossiliferous zones of the Durness dolomite and limestone. He states that "the latter fauna is so similar to, if not identical with, that occurring in Newfoundland, Mingan Islands, and Point Levis, beneath strata yielding the Phyllograptus fauna of Arenig age, that the beds must be regarded as belonging to the higher divisions of the Cambrian formation."

The intrusive igneous rocks of the Assynt region, of later date than Cambrian time, and yet older than the post.Cambrian movements, have been specially studied by Mr. Teall, who has obtained results of special importance from a petrological point of view. This petrographical province embraces the plutonic complex of Cnoc na Sroine and Loch Borolan, and the numerous sills and dykes that traverse the Cambrian and Torridonian sediments, and even the underlying platform of Lewisian gneiss. He infers that the plutonic rocks have been formed by the consolidation of alkaline magmas rich in soda. At the one end of the series is the quartz-syenite of Cnoc na Sroine, and at the other the basic augite-syenite, nepheline-syenite, and borolanite. The basic varieties occur on the margin, and the acid varieties in the centre. The sills and dykes comprise two wellmarked types, camptonites or vogesites, and felsites with alkal felspar and xgirine, which he believes to represent the dyke form of the magmas that gave rise to the plutonic mass (Geol. Mag., December 4, vol. vii. p. 385 , 1900).

The striking feature in the geology of the North-west Highlands is the evidence relating to those terrestrial movements that affected that region in post-Cambrian times, which are without a parallel in Britain. The geological structures produced by these displacements are extremely complicated, but the vast amount of evidence obtained in the course of the survey of that belt clearly proves that, though the sections vary indefinitely along the line of complication, they have certain features in common which throw much light on the tectonics of that mountain chain. Some of these features may thus be briefly summarised.

(I) By means of lateral compression or earth-creep the strata are thrown into a series of inverted folds which culminate in reversed faults or thrusts.

(2) Without incipient folding, the strata are repeated by a series of minor thrusts or reversed faults which lie at an oblique angle to the major thrust-planes and dip in the direction from which the pressure came, that is, from the east.

(3) By means of majur thrusts of varying magnitude the following structures are produced: $(a)$ the piled-up Cambrian strata are driven westwards along planes formed by the underlying undisturbed materials ; $(b)$ masses of Lewisian gneiss, Torridon Sandstone, and Cambrian rocks are made to override the underlying piled-up strata; $(c)$ the Eastern Schists are driven westwards and, in some cases, overlap all major and minor thrusts till they rest directiy on the undisturbed Cambrian strata.

When to these features are added the effects of normal faulting and prolonged denudation, it is possible to form some conception of the evolution of those extraordinary structures which are met with in that region. Some of the features just described occur in other mountain chains affected by terrestrial movement, as in the Alps and in Provence; but there is one which appears to be peculiar to the North-west Highlands. It is the remarkable overlap of the Moine Thrust-plane-the most easterly of the great lines of displacement. Along the southern confines of the wild and complicated region of Assynt, that plane can be traced westwards for a distance of six miles to the Knockan cliff, where the micaceous flagstones rest on the Cambrian limestone. In Durness we find an outlier of the Eastern Schists re. posing on Cambrian limestone, there preserved by normal faults, at a distance of about ten miles from the mass of similar schists east of Loch Eriboll, with which it was originally continuous.

Though many of these structures appear incredible at first, it is worthy of note that some have been reproduced experimentally by Mr. Cadell (Trans. Roy. Soc. Edinburgh, vol. xxxv. p. 337). He took layers of sand, loam, clay, and plaster of Paris, and after the materials had set into hard brittle laminæ, in imitation of sedimentary strata, he applied horizontal pressure under varying conditions. The results, some of which may here be given, were remarkable.

(I) The compressed mass tends to find relief along a series of gently inclined thrust-planes, which dip towards the side from which pressure is exerted.

(2) After a certain amount of heaping up along a series of minor thrust-planes, the heaped-up mass tends to rise and ride forward bodily along major thrust-planes.

(3) The front portion of a mass being pushed along a thrustplane tends to bend over and curve under the back portion.

(4) A thrust-plane below may pass into an anticline above ; and a major thrust-plane above may and probably always does originate in a fold below.

Now these important experiments confirm the conclusion reached by the Geological Survey from a study of the pheno-

NO. I 664 , VOL. 64$]$ 
mena in the field, viz., that under the influence of horizontal compression or earth-creep the rocks in that region behaved like brittle rigid bodies which snapped across, were piled up and driven westwards in successive slices. But, further, these displacements were accompanied by differential movement of the materials which resulted in the development of new structures. These phenomena culminate along the belt of rocks in immediate association with the Moine Thrust, where the outcrop of that thrust lies to the east of a broad belt of displaced materials. There, Lewisian gneiss, Torridon Sandstone, and Cambrian quartzite are sheared and rolled out, presenting new divisional planes parallel with that of the Moine Thrust. The Lewisian gneiss shades into flaser gneiss and schist, and ultimately passes into a banded rock like a platy schist. The pegmatites show fluxion structure with felspar " eyes" like that of the rhyolites. At intervals in these zones of highly sheared rocks, phacoidal masses of Lewisian gneiss appear, in which the pre-Torridonian structures are not wholly effaced. The sills of camptonite and feisite intrusive in the Cambrian rocks become schistose and together with the sediments in which they occur appear in a lenticular form. All these mylonised rocks show a characteristic striping on the divisional planes, due to orientation of the constituents in the direction of movement.

Still more important evidence in relation to the question of regional metamorphism is furnished by the Torridon Sandstone. In the case of the basal conglomerate the pebbles have been flattened and elongated, and a fine wavy structure has been developed in the matrix. In the district of Ben More, Assynt planes of schistosity, more or less parallel with the planes of the Ben More Thrust, pass downwards from the Torridon conglomerate into the underlying gneiss. Both have a common foliation irrespective of the unconformability between them. Again, along the great inversion south of Stromeferry, foliation has been developed in the Torridon conglomerate and overlying Lewisian gneiss, parallel to the plane of the Moine Thrust. The Torridon grits and sandstones south of Kinlochewe and between Kishorn and Loch Alsh are similarly affected by the post-Cambrian movements. Mr. Teall has shown that the quartz grains have been drawn out into lenticles and into thin folia that wind round "eyes" of felspar. A secondary crypto-crystalline material has been produced, sericitic mica appears in the divisional planes, and in some instances biotite is developed. In short, he concludes that in these deformed Torridonian sediments there is an approximation to the crystalline schists of the Moine type. The stratigraphical horizon of these rocks can be clearly proved. The subdivisions of the Torridon Sandstone have been recognised in those displaced masses which lie to the east of the Kishorn Thrust and to the west of the Moine Thrust. It is worthy of note also that in the belt of highly sheared gneiss south of Stromeferry that comes between the Torridonian in version in the west and the Moine Thrust on the east, $\mathrm{Mr}$. Peach has found folded and faulted inliers of the basal division of the Torridon Sandstone that have a striking resemblance to typical Moine schists.

Regarding the age of these post-Cambrian movements, it is obvious that they must be later than the Cambrian limestone and older than the Old Red Sandstone, for the basal conglomerates of the latter rest unconformably on the eastern schists and contain pebbles of basal quartzite, pipe-rock, limestone, and dolomite derived from the Cambrian rocks of the North-west Highlands.

East of the Moine Thrust or great line of displacement extending from Eriboll to Skye, we enter the wide domain of the metamorphic rocks of the Highlands, a region now under investigation, and which presents difficult problems for solution. Two prominent types of crystalline schists (Caledonian series, Callaway, and Moine schists of the Geological Survey) have been traced over wide areas in the counties of Sutherland, Ross, and Inverness, and across the Great Glen to the northern slopes of the Grampians. Consisting of granulitic quartzose schists and muscovite-biotite schist or gneiss, they appear to be of sedimentary origin, though crystalline. They are associated with recognisable masses of Lewisian gneiss covering many square miles of ground and presenting many of the structures so characteristic of that complex in the undisturbed areas already described. Within the belt of Lewisian gneiss at Glenelg Mr. Clough has mapped a series of rocks presumably of sedimentary origin, including graphitic schists, mica schists, and limestones, but the gneiss with which they are associated possesses granulitic structure like that of the adjoining Moine schists ("Sum-

$$
\text { NO. I664, vOL. } 64]
$$

mary of Progress of the Geological Survey for 1897," p. 37). Further, in the east of Sutherland, and also in the county of Ross, foliated and massive granites appear which are interleaved in the adjoining Moine schists, forming injection gneisses and producing contact metamorphism.

In the Eastern Highlands the Moine series disappears and is replaced by a broad development of schists, admittedly of sedimentary origin, which have been termed the Dalradian series by Sir A. Geikie. Within recent years it has been divided into certain rock-groups which have been traced by the Geological Survey from the counties of Banff and Aberdeen to Kintyre. It has been found that, though highly crystalline in certain areas, they pass along the strike into comparatively unaltered sediments, as proved by Mr. Hill in the neighbourhood of Loch Awe ("Annual Report of the Geological Survey for 1893," p. 265). Before the planes of schistosity were developed in these Dalradian schists they were pierced by sills of basic rock (gabbro and epidiorite) and acid material (granite), both of which must have shared in the movements that affected the schists, as they merge respectively into hornblende schists and foliated granite or biotite gneiss. Buth seem to have developed contact metamorphism; indeed, Mr. Barrow ${ }^{2}$ contends that the regional metamorphism so prominent in the south-east Highlands is mainly, if not wholly, due to the intrusion of an early granite magma, now exposed at the surface in the form of local bosses of granite and isolated veins of pegmatite.

The age of the Dalradian schists has not been determined. Though there seems to be an apparent order of superposition, in this series it is still uncertain whether that implies the original sequence of deposition. Since Sir A. Geikie applied the term Dalradian to the Eastern Highland schists in I891 (Quart. Journ. Geol. Soc., vol. xlvii. p. 72), evidence has been obtained ("Annual Report of the Geological Survey for I 893," p. 266; for 1895, p. 25 ; for 1896, p. 27 ) that suggests the correlation of certain rocks along the Highland border with the Arenig and younger Silurian strata of the Southern Uplands. Consisting of epidiorite, chlorite schist, radiolarian cherts, black shales, grits, and limestone, they have been traced at intervals from Arran to Kincardineshire. In the latter region Mr. Barrow contends that they are separated by a line of disruption from the Highland schists to the north; but no such discordance has been detected in the Callander district or in Arran. Though these rocks of the Highland border have been much deformed, yet their occurrence in the same order of succession in that region and in the Southern Uplands is presumptive cridence for their correlation.

In view of this evidence it is not improbable that the Dalradian series may contain rock-groups belonging to different geological systems. Indeed, the result of recent Survey work in Islay tends to support this view. For in the south-west part of that island there is a mass of Lewisian gneiss overlaid unconformably by sedimentary strata which have been correlated with the lower and middle divisions of the Torridon Sandstone. Un. fortunately the sequence ends here, as both the gneiss and overlying sediments are separated by a line of disruption or thrust-plane from the strata in the eastern part of the island. And yet, notwithstanding this break, the evidence obtained in the latter district is remarkable, whatever theory be adopted to explain it. There the Islay limestone and black slates appear to be covered unconformably by the Islay quartzite containing Annelid tubes and followed in ascending sequence by Fucoidal shales and dolomites, suggestive of the Cambrian succession in Sutherland and Ross. The Islay quartzite passes into Jura, thence to the mainland, and it may eventually prove to be the Perthshire quartzite, while the Islay limestone and black slate are supposed to be the prolongations of the limestone and slate of the Loch Awe series in Argyllshire ("Summary of Progress for 1899 ," p. 66).

From the foregoing data it will be seen that much uncertainty prevails regarding the age and structural relations of the metamorphic rocks of the Highlands, but the difficulties that here confront the observer are common to all areas affected by regional metamorphism.

A prominent feature in the geology of the Eastern Highlands is the great development of later plutonic rocks chiefly in the

1 "On Foliated Granites and their Relations to the Crystalline Schists in Eastern Sutherland" (Quart. Journ. Geol. Soc., vol. lii. p. 633). 2 "Intrusion of Muscovite-biotite Gneiss in the South-east Highland and its accompanying Metamorphism" (Quart. Journ. Geol. Soc., vol. xlix. p. 330) 
form of granite ranging along the Grampian chain from Aberdeenshire to Argyllshire. In connection with one of these masses a remarkable paper appeared in 1892 which in my opinion has profoundly influenced petrological inquiry in Scotland from the light which it threw on the relations of a connected series of petrographical types in a plutonic complex. I refer to the paper on the "Plutonic Rocks of Garabal Hill and Meall Breac," by Mr. Teall and Mr. Dakyns (Quart. Fourn. Geol. Soc., vol. xlviii. p. IO4).

The authors showed that this plutonic mass comprises granite, tonalite, augite-diorite, picrites, serpentine, and other compounds. Mr. Teall regards the members of this sequence as products of one original magma by a process of differentiation, the peridotites being the oldest rocks, because the minerals of which they are composed are the first to form in a plutonic magma. As the process of consolidation advances, rocks of a varied composition arise, in the order of increasing acidity, viz., diorites, tonalites, and granites. The most acid rock consists of quartz and orthoclase, which may represent the mother liquor after the other constituents had separated out. Mr. Teall concludes that progressive consolidation of one reservoir gives rise to the formation of magmas of increasing acidity, and hence that basic rocks should precede the acid rocks. This theory of magmatic differentiation-so strenuously advocated by Brögger Vugt, Rosenbusch, Iddings, Teall. and others-was first applied to the interpretation of varied types of plutonic masses in Scotland by Mr. Teall in the paper referred to. Since then he has extended its application to the granite masses in the Silurian tableland of the south of Scotland, which include rocks, ranging from hyperites at the one end to granitite with microcline, and aplite veins at the other. ${ }^{1}$ Many of the phenomena presented by the newer granite masses of the Eastern Highlands seem to lend support to this theory. These views, indeed, have permeated the petrological descriptions of the granitic protrusions in the counties of Aberdeen and Argyll which have been given by Messrs. Barrow, Hill, Kynaston, and Craig ${ }^{2}$ in recent years.

One of the remarkable advances in Scottish geology during the period under review is the solution of the order of succession and tectonic relations of the Silurian rocks of the south of Scotland by Prof. Lapworth. The history of research relating to that tableland, and of all his contributions to the problems connected with it, has been given in detail in the recent volume of the Geological Survey on that formation. At present it will be sufficient to refer to his three classic papers, which, in my opinion, record one of the great achievements in British geology. The first, on "The Moffat Series" (Quart. Journ. Geol. Soc., vol. xxxiv. p. 240), demonstrated, by means of the vertical distribution of the graptolites, the order of succession in those fine deposits (black shaies and mudstones), which were laid down near the verge of sedimentation, and are now exposed in anticlinal folds in the central belt. The second, on "The Girvan Succession" (ibid., vol. xxxviii. p. 537), showed how certain graptolite zones of the Moffat shales are interleaved, in the Girvan region, with conglomerates, grits, sandstones, flagstones, mudstones, shales, and limestones, charged with all the varied forms of life found in shallow seas or near shore. In the third, on "The Ballantrae Rocks of the South of Scotland and their Place in the Upland Sequence" (Geol. Mag., December 3 , vol. vi. p. 20), he indicated the distribution and variation of the Moffat terrane (Upper Llandeilo to Upper Llandovery) and of the Gala terrane (Tarannon), which form the greater part of the uplands. He further pointed out how the rocks and the fossils vary across the uplands according to the conditions of deposition. Finally he proved that the complicated tectonics of the Silurian tableland, its endless overfolds, its endoclinal and exoclinal structures, can be unravelled by means of the graptolite zones. These researches disposed of the order of succession based on Barrande's doctrine of Colonies, and established the zonal value of graptolites as an index of stratigraphical horizons. So complete was the zonal method of mapping adopted by Prof. Lapworth, and so accurate were his generalisations, that few modifications have been made in his ork.

1 " Annual Report of the Geological Survey for 1896," p. 40 ; see also "The Silurian Rocks of Scotland" (Geological Survey Memoir, 1899, p. 607 ).

$2{ }_{2}$ "Annual Report of the Geological Survey for 1897, " p. 87 ; for 1898 , pp. 25-28; see also paper on "Kentallenite and its Relations to other
Igneous Rocks in Argyllshire" (Quart. Journ. Geol. Soc., vol. lvi. p. 531 ).

NO. [ 664, VOL. 64]
In the course of the re-examination of the Silurian tableland by the Geological Survey some important additions were made to our knowledge of the Silurian system as there developed. Underlying all the sediments of the uplands there is a series of volcanic and plutonic rocks of Arenig age, the largest development of which occurs at Ballantrae in Ayrshire, where their igneous character was recognised by Prof. Bonney. But they appear in the cores of numerous anticlines over an area of about I 500 square miles, forming one of the most extensive volcanic areas of Palæozoic age in the British Isles. These volcanic rocks are overlain by a band of cherts and mudstones, succeeded by black shales yielding Glenkiln graptolites of Upper Llandeilo age. The cherts, which are abundantly charged with Radiolaria, implying oceanic conditions of deposition, are about 70 feet thick, and have been traced over an area of about 2000 square miles. The deposition of the Radiolarian ooze must have occupied a long lapse of time. Indeed the cherts and mudstones represent the strata which, in other regions, form the Upper Arerig and Lower Llandeilo divisions of the Silurian system. They furnish interesting evidence of the nceanic conditions which here prevailed in early Silurian time, and form a natural sequel to Prof. Lapworth's researches bearing on the graptolitic deposits of the Upper Llandeilo period, which must have been laid down on the sea-floor near the limit of the land-derived sediment.

Of special interest is the new fish fauna found by the Geological Survey in the Ludlow and Downtonian rocks between Lesmahagow and Muirkirk, which the researches of Dr. Traquair have shown to be of great biological and palæontological value (Trans. Roy. Soc. Edin., vol. xxxix. p. 827). This discovery has enabled him to give a new classification of the Ostracodermi, to enlarge the order of the Heterostraci, which now includes four families, instead of the Pteraspidae alone. He has further shown that the Coelolepidae were not Cestraciont sharks to which the Onchus spines belonged, but Heterostraci, though probably of Elasmobranch origin, judging from the shagreen-like scales. The Coelolepidae are common fishes in the Ludlow and Downtonian rocks of Lanarkshire. The genus, Thelodus, first described by Agassiz from detached scales in the Ludlow bone-bed, and subsequently figured and described by Pander and Rohon from scales in the Upper Silurian rocks of Oesel, is here represented for the first time by nearly complete forms. But it is remarkable that no Onchus spines, nor any Pteraspidae, nor Cephalaspidae have been found in the Lanarkshire strata, the nearest related genus to Cephalaspis being Ateleaspis, which, however, represents a distinct family.

The group of sandstones, conglomerates, shales, and mudstones that form the passage-beds between the Ludlow rocks and the Lower Old Red Sandstone in Lanarkshire are now regarded as the equivalents of the Downtonian strata in Shropshire, and are linked with the Silurian system. The mudstones of this group, containing the new fish fauna, likewise yield ostracods, phyllocarid crustaceans, and eurypterids-forms which connect these beds with the underlying Ludlow rocks. The band of greywacke-conglomerate, that extends from the Pentland Hills into Ayrshire, composed largely of pebbles derived from the Silurian tableland, is now taken as the base line of the Lower Old Red Sandstone on the south side of the great midland valley of Scotland.

The period under review has been marked by important additions to our knowledge of the Old Red Sandstone formation. In 1878 appeared a valuable monograph by Sir Archibald Geikie on "The Old Red Sandstone of Western Europe" (Trans. Roy. Soc. Edin., vol. xxviii. p. 345), by far the most important treatise on this subject since the publication of Hugh Miller's classic work published in 184I. Following up the view maintained by Fleming, Godwin-Austen, and Ramsay, that the deposits of this formation were laid down in lakes or inland seas, he defined the geographical areas of the various basins in the British area, giving to each a local name. He gave an outline of the development of the rocks north of the Grampians, in Caithness, Orkney, and Shetland. He advanced an ingenious argument in favour of correlating the Caithness flagstone series (middle division, Murchison) with the Lower Old Red Sandstone south of the Grampians. He contended that "the admitted palæontological distinctions between the two areas are probably not greater than the striking lithological differences between the strata would account for, or than the contrast between the ichthyic faunas of adjacent but disconnected water basins at the present time." Sir A. Geikie 
further gave a table showing the vertical range of the known fossils of the Caithness series from data partly supplied by the late Mr. C. Peach.

During the last quarter of a century Dr. Traquair has made a special study of the ichthyology of the Old Red Sandstone and Carboniferous strata of Scotland, which has enabled him to throw much light on the distribution of fossil fishes in these rocks and on their value for the purpose of correlation. His researches show that the fish fauna of the formation south of the Grampians resembles that of the Lower Old Red Sandstone of the West of England and adjoining part of Wales in the abundance of specimens of Cephalaspis, the common species in Forfarshire (C. Lyelli, Ag.) being also indistinguishable from that in the Herefordshire beds. Pteraspis occurs in both regions, though of different species. Of Acanthodians Parexus recur. vus, Ag., occurs in both, together with Climatius (C. ornatus, Ag.). The abundance of Cephalaspis (C. Campbelltonensis, Whit., C. Texi, Traq.) and of Climatius spines is characteristic of the Lower Devonian rocks of Canada.

The Old Red Sandstone of Lorne has recently yielded organic remains, akin to those found in Forfarshire, south of the Grampians, viz., Cephalaspis Lornensis, Traq., two species of myriapods (Campecaris Forfarensis and a species of Archidesmus ("Summary of Progress, Geological Survey, 1897," p. 83).

In the deposits of Lake Orcadie, north of the Grampians, quite a different fish fauna from that of Forfarshire appears. Dr. Traquair has noted that there are no species common to the two areas, and only two genera, viz., Mesacanthus and Cephalaspis. The latter genus is, however, represented in Caithness only by a single specimen of a species (C. magnifica, Traq.) different from any found elsewhere. It might here be observed that Cephalaspis is represented also in the Upper Devonian rocks of Canada by a single specimen of a peculiar species ( $C$. laticeps, Traq.), and hence Dr. Traquair has shown that, though Cephalaspis is most abundant in the Lower Devonian, it extends also into the upper division of that system. It further appears that Osteolepidae (Osteolepis, Diplopterus), Rhizodontidae (Tristichopterus, Gyroptychius), Holoptychiidae (Glytolepis), Asterolepidae (Pterichthys, Microbrachius), Ctenodontidae (Dipterus) are abundant in the Orcadian fauna, none of which has occurred in the Lower Old Red Sandstone of Forfarshire, the West of England, or in the Lower Devonian rocks of Canada. Dr. Traquair recognised, however, the identity of the fishes from the well-known fish band in the basin of the Moray Firth with those brought from the west part of Orkney, though these forms did not quite agree with the fossils from the Thurso district. He subsequently found that the fish fauna from the Orcadian beds in the Moray Firth basin is represented in Caithness by that of Achanarras; and, further, that two other faunas occur in the Caithness area-that of Thurso and that of John o' Groats as given below :-

$\begin{array}{ll}\text { John o' Groats... } & \left\{\begin{array}{l}\text { Tristichopterus alatus, Egert. } \\ \text { Thurso } \\ \text { Achanarras }\end{array} \ldots\right.\end{array}\left\{\begin{array}{l}\text { Microbrachius Dicki, Traq. } \\ \text { Coccosteus minor, H. Miller. } \\ \begin{array}{l}\text { Thursius pholidotus, Traq. } \\ \text { Osteolepis microlepidotus, Pander. } \\ \text { Plerichthys, 3 species. }\end{array} \\ \begin{array}{l}\text { Cheirolepis Trailli, Ag. } \\ \text { Osteolepis macrolepidotus, Ag. }\end{array}\end{array}\right.$

In 1898 appeared an important paper by Dr. Flett on "The Old Red Sandstone of the Orkneys" (Trans. Roy. Soc. Edin., vol. xxxix. p. $3^{8} 3$ ), in which he described the results of his detailed examination of the islands. He proved the existence there of three fish faunas, and their correspondence with those identified in Caithness by Dr. Traquair. From the evidence in the field he adopted the following order of succession and correlation of the strata:-

3. Eday Sandstones and John o' Groats beds.

2. Rousay and Thurso beds.

I. Stromness, Achanarras, and Cromarty beds.

A further important result of Dr. Flett's researches in the Old Red Sandstone of these northern isles was communicated to the Royal Society of Edinburgh this year. He has found in the Shetland beds, which had previously yielded no fossils save plants, fragments, identified by Dr. Traquair as Holonema, a fish new to Britain, but occurring in the Chemung group of North America, the subdivision of the Upper Devonian that immediately underlies the Catskill red sandstones, with remains of Holoptychius. Dr. Traquair has also recognised in Dr. Flett's collection fragments of Asterolepis, a genus characteristic of the Upper Old Red Sandstone, and which, as proved by Dr. Flett, occurs in the "Thurso beds" of the Orkneys. The interest attaching to this discovery is very great, for Dr. Flett contends that it indicates a fourth life-zone in the Orcadian series, and, further, that it tends to span the break between the Orcadian division and Upper Old Red Sandstone.

In the Upper Old Red Sandstone on the south side of the Moray Firth, Dr. Traquair recognised two life-zones, and sub. sequently, with the assistance of Mr. Taylor, Lhanbryde, a third, in the following order. The lowest is that of the Nairn sandstones with Asterolepis maxima, Ag. ; the second, that of Alves and Scaat Craig with Bothriolepis major, Ag., Psammosteus Taylori, Traq. ; and the highest that of Rosebrae, the fauna of which, according to Dr. Traquair, has a striking resemblance to the assemblage in the Dura Den Sandstones in Fife.

Before 1876 all the Carboniferous areas in the great midland valley of Scotland had been mapped by the Geological Survey. The extent and structural relations of the various coal-fields were determined according to the information then available, and shown in the published maps. But the rapid development of certain fields in the east of Scotland necessitated a revision of them which has lately been done. The Fife coal-field has been re examined by Sir A. Geikie, Mr. Peach and Mr. Wilson, and the oil-shale fields in the Lothians have been mapped by Mr. Cadell. An important memoir by Sir A. Geikie on "The Geology of Central and Western Fife and Kinross" has just been issued by the Geological Survey, in which the structure of these coal-fields is described. Mr. Cadell lately gave an account of the geological structure of the oil-shale fields in his presidential address to the Edinburgh Geological Society.

Within the period under review detailed researches of great importance on the fossil flora of British Carboniterous rocks have been carried out by Mr. Kidston, to which reference ought to be made. The results are of the highest value for correlating the strata in different areas. ${ }^{1}$ By means of the plants he arranges the Carboniferous rocks of Scotland in two great divisions : a lower, comprising the Calciferous Sandstone and Carboniferous Limestone series; and an upper, including the Millstone Grit and the Coal-measures, there being a marked palæontological break at the base of the Millstone Grit. He shows that the upper and lower divisions of the system, not only in Scotland but in Britain, are characterised by a different series of plants, not one species passing from the lower division-save in the case of Stigmaria-into the upper. From his researches it appears that, among ferns, Neuropteris is all but unknown in the lower division, whereas in the upper it is very abundant. The Sphenopterids are proportionately common in both divisions; but those of the lower are usually characterised by cuneate segments, while those of the upper have generally rounded pinnules. Alethopteris, so common throughout the whole of the upper series, is entirely absent from the lower. The genus Calamites, which is extremely plentiful in the upper, is almost entirely absent from the lower division, where its place is taken by Asterocalamites. The Cordaiteae are also rare below the Millstone Grit, though very plentiful above that horizon. Sicillaria, so rare in the Lower Carboniferous rocks, is extremely abundant in the upper division, and particularly in the middle Coal-measures. In short, Mr. Kidston concludes that the floras of the two main divisions of the Carboniferous system, though belonging to the same types, are absolutely distinct in species, and in the relative importance of the genera.

By means of the fossil plants Mr. Kidston correlates the Coalmeasures of Scotland underlying the red sandstones with the lower division of the Coal-measures of England, and the overlying red sandstones of Fife with the middle division of the English Coal-measures.

It is remarkable that the evidence supplied by the fossil fishes has led Dr. Traquair independently to a similar conclusion. $\mathrm{He}$ holds that fossil ichthyology proves the existence of only two great life-zones in the Carboniferous rocks of Central Scotlandan upper and a lower-the boundary line between the two being drawn at the base of the Millstone Grit. The Scottish Carboniferous rocks, being mostly estuarine, give an opportunity of comparing the estuarine fishes of both divisions. He finds the Coal-measure fishes of Scotland to be the same as those in the English Coal-measures, while those occurring below the

1 " On the Various Divisions of British Carboniferous Rocks as deter mined by their Fossil Flora," Proc. Roy. Phys. Soc. Edin., vol, xii. p. 183 r 893).

NO. I664, VOL. 64] 
Millstone Grit in Scotland are mostly different in species, and often, too, in genera, from the forms above that horizon.

Of special interest as bearing on the former extension of this system in Scotland is the discovery made by Prof. Judd (Quart. Journ. Geol. Soc., vol. xxxiv. p. 685) in I 877 of a patch of Carboniferous sandstones and shales, with well-preserved plant remains in Morven. Another small outlier of this formation has recently been found in the Pass of Brander by the Geological Survey ("Summary of Progress, Geological Survey," I898, p.. 129).

The reptiles from the Elgin sandstones, recently described by Mr. E. T. Newton (Phil. Trans., vol. clxxxiv. I893, p. 43I); ibid., vol. clxxxv., I894, p. 573), add fresh interest to the study of these rocks. The structural relations of these sandstones have been fully treated by Prof. Judd in his great paper on the Secondary Rocks on the east of Scotland (Quart. Journ. Geol. Soc., vol. xxix. p. 98), and again in his presidential address to this Section at Aberdeen (Rep. Brit. Assoc. for I 885, p. 994), who confirmed Huxley's well-known correlation of these beds with the Trias. The Dicynodont skull, identified by Prof. Judd and Dr. Traquair at the Aberdeen meeting of the British Association in 1885 , and other remains found in the reptilian sandstones in Cutties Hillock Quarry, where they rest on Upper Old Red Sandstone with Holoptychius, have been described by Mr. Newton. He confirmed their affinity with Dicynodonts, though they were referred to the genera Gordonia and Geikia. But the most remarkable specimen was the skull named by $\mathrm{Mr}$. Newton Elginia mirabilis. This extraordinary creature, with a pair of horns projecting like those of a short-horned ox, and with smaller spines and bosses, numbering thirty-nine, is related to the great Pareiasaurus from the Karoo beds of South Africa. Two other reptiles are described by Mr. Newton from this quarry, namely, a small crocodile-like animal, Erpetosuchus Granti-apparently nearly allied to Stagonolepis-and Ornithosuchus Woodwardi, which is probably a small Dinosaurian.

Mr. Newton has raised an interesting point in connection with his researches. $\mathrm{He}$ calls attention to the fact that the reptilian remains from the Cutties Hillock Quarry differ from those found at other localities in the Elgin district. For example, the Lossiemouth sandstones have yielded Stagonolepis, Hyperodapedon and Telerpeton; and the Cutties Hillock sandstones, the Dicynodonts (Gordonia and Geikia), the horned reptile (Elginia), the small crocodile-like Erpetosuchus, and the little Dinosaurian Ornithosuchus. Does this distribution indicate different stratigraphical horizons? is viritually the poin raised by Mr. Newton. In connection with this inquiry he cites the evidence obtained in other countries. Thus, in the Gondwana beds of India, the series of reptiles similar to those of Elgin occur at different localities and on different stratigraphical horizons; Dicynodonts and Labyrinthodonts being found in the lower Panchet rocks, while Hyperodapedon and Parasuchus (allied to Stagonolepis) are met with in the higher Kota-Maleri beds. Again in the Karoo beds of South Africa the Dicynodonts and the great Pareiasaurus - the latter being the nearest known ally of the horned reptile (Elginia mirabilis) from Cutties Hillock, Elgin-occur low down in that formation. Further light is thrown on the question by the interesting discoveries of Amalitzky in Northern Russia, where a number of reptilian remains have been found closely allied to Pareiasdurus, Elginia and Dicynodon, in beds, which are referred to the Permian formation and accompanied by plants and mollusca which seemingly confirm this reference. ${ }^{1}$

In view of these foreign discoveries $\mathrm{Mr}$. Newton concludes that the Elgin sandstones may probably represent more than one reptilian horizon, and that we are confronted with the possibility of their being of Permian age.

The difficulty of drawing a boundary line between the Trias and the Upper Old Red Sandstone of Elgin, which impressed the mind of the late Dr. Gordon, has had to be faced elsewhere in Scotland. In Arran, my colleague, Mr. Gunn, has shown that the Trias there rests on Upper Old Red Sandstone, both formations having a similar inclination. Even he, with his ripe experience, has had great difficulty in drawing a boundary between them on the west side of the island; but when the base line of the Trias is traced eastwards to Brodick it passes transgressively on to Carboniferous rocks.

Of special importance is the recent discovery in Arran of the fossils of the Avicula contorta zone ("Summary of Progress,

a Y. Amalitzky, "Sur les fouilles de 1899 de débris de vertébrés dans les dépôts Permiens de la Russie du nord." (Varsovie, rgoo.)
Geological Survey, 1899," p. 133) by Mr. Macconochie, of the Geological Survey, to whose skill as a fossil collector Scottish geology owes much. With these occur Lower Liassic fossils, in sediments which are not now found in place in the island. These fossiliferous patches are associated with frammental volcanic materials filling a great vent, the age of which will be referred to presently. This discovery has fixed the Triassic age of the red sandstones and marls in the south of Arran. The detailed mapping of the island by Mr. Gunn has demonstrated that the Triassic sandstones rest partly on the Old Red Sandstone, partly on the Carboniferous Limestone Series and partly on the Coal-measures.

In 1878 appeared the third of Prof. Judd's great papers on the Secondary Rocks of Scotland, wherein he unravelled the his. tory of these strata as developed in the east of Scotland and in the West Highlands. His admirable researches, in continuation of the work done by Bryce, Tate and others embraced the identification of the life-zones, their correlation with those of other regions, the history of the physical conditions which prevailed in Scotland during Mesozoic time, and the working out of the structural relations of the strata (Quart. Journ. Geol. Soc., vol. xxix. p. 97, vol. xxxiv. p. 660). He showed that their preservation on the east of Scotland was due to the existence of great faults, and those in the West Highlands to the copious outpouring of the Tertiary lavas. He was the first to detect the occurrence of Cretaceous rocks in the West Highlands, and to show the marked unconformability which separates them from the Jurassic strata. His main life-zones and his main conclusions regarding the Secondary Rocks of Scotland have so far been confirmed by the detailed mapping of the Geological Survey. An interesting addition to our knowledge of these rocks was made by my colleague, Mr. Woodward, in the course of his field work, who found the oolitic iron ore in the Middle Lias of Raasay, the position of which corresponds approximately with that of the Cleveland ironstone (Geol. Mag., December 3, vol. x. p. 493 (I 893 )

The extensive plateau of Tertiary volcanic rocks in the Inner Hebrides has been a favourite field of research ever since the time of Macculloch, the great pioneer in West Highland geology. During the period under review much work has been done in that domain. According to Prof. Judd, that region contains the relics of five great extinct volcanoes and several minor cones, indicating three periods of igneous activity. The first was characterised by the discharge of acid lavas and ashes, the molten material consolidating down below as granite; the second by the outburst of basic lavas, now forming the basaltic plateau, connected with deep-seated masses that appear now as gabbro and dolerite; the third by the appearance of sporadic cones, from which issued minor streams of lava (Quart. Journ. Geol. Soc., vol. xxx, p. 220).

In I $888 \mathrm{Sir} \mathrm{A}$. Geikie communicated his elaborate monograph on the history of Tertiary volcanic action in Britain to the Royal Society of Edinburgh (Trans. Roy. Soc. Edin., vol, xxxv., part 2, p. 23), which has been incorporated, with fuller details, in his recent work on "The Ancient Volcanoes of Great Britain." His main conclusions may thus be briefly stated : (I) The great basaltic plateaux did not emanate from central volcanoes, but are probably due to fissure eruptions; (2) the basaltic lavas were subsequently pierced by laccolitic masses of gabbro, which produced a certain amount of contact alteration on the previously erupted lavas ; $(3)$ the protrusion of masses of granophyre and other acid materials by means of which the basic rocks were disrupted.

During the last six years Mr. Harker has been engaged in mapping the central part of the isle of Skye, and in the petrographical study of the rocks, the results of which have been summarised in the annual reports of the Geological Survey. As regards the basaltic lavas, he firds that while they have been of vast extent the individual flows have been of feeble volume, and show no evident relation to definite centres of eruption. There were two local episodes, however, which took the form of central eruptions: one represented by a number of explosive outbursts at certain points; the other, in the basalt succession, gave rise to rhyolitic rocks.

Mr. Harker further finds that the succeeding plutonic phase of activity, confined in Skye to what is now the central mountain tract, is represented by three groups of plutonic intrusions, in the following order: peridotites, gabbros and granites. The metamorphism set up in the basaltic lavas near the large plutonic masses presents points of interest, especially the

NO. I664, VOL. 64] 
widespread formation of new lime-soda-felspars from the zeolites in the lavas.

After the intrusion of the granite of the Red Hills, Mr. Harker finds that igneous activity took the form of intrusions of smaller volume, but in some cases of wide distribution. The great group of dolerite sills belongs to this period. An enormous number of acid and basic dykes followed, of several distinct epochs. A set of minor basic intrusions of quite late date is found in the gabbro district of the Cuillins, the most interesting of which takes the form of sheets of dolerite, parallel at any given locality, but always dipping towards the centre of the gabbro area. Mr. Harker considers that this remarkable system of injections presents a new problem in the mechanics of igneous intrusion. The latest phase of vulcanicity in the Cuillin district is a radial group of peridotite dykes. As regards the local group of rock in Central Skye Mr. Harker finds that the order of increasing acidity which ruled in the plutonic phase was reversed for the minor intrusions which followed.

In connection with the great development of volcanic activity in the West of Scotland in Tertiary time reference must be made to the remarkable volcanic vent in Arran the recognition of which is due to the suggestion of my friend Mr. Peach. This volcanic centre covers an area of about eight square miles, and lies to the south of the granite area of the island (Quart. Tourn. Geol. Soc., vol. lvii. p. 226 (I 901 ). The vent is now filled with volcanic agglomerate and large masses of sedimentary material, some of which have yielded the Rhrtic and Lower Lias fossils already referred to, the whole being pierced by acid and basic igneous rocks. One of the interesting features connected with it is the occurrence of fragments of limestone with the agglomerate, which has yielded fossils of the age of the chalk, thus proving that the vent is post-Cretaceous. There is thus strong evidence for referring the granite mass in the north of the island and most of the intrusive, acid, and basic igneous rocks to the Tertiary period. It furnishes remarkable proof of the suggestion of the Tertiary age of the Arran granite made by Sir A. Geikie in 1873 (Trans. Geol. Soc. Edin., vol. ii. p. 305). The story unfolded by this discovery is like a geological romance. The former extension of Rhætic and Lower Lias strata and of the chalk in the basin of the Clyde, and the evidence of extensive denudation in the south of Scotland, appeal vividly to the imagination.

This outline of the researches in the solid geology of Scotland would be incomplete without reference to the publication of Sir A. Geikie's great work on "The Ancient Volcanoes of Great Britain" (1897), in which the history is given of volcanic action in Scotland from the earliest geological periods down to Tertiary time. To investigators it has proved invaluable for reference. Nor can I omit to mention the new edition of his volume on "The Scenery of Scotland," wherein he depicts the evolution of the topography of the country with increasing force and fascination. In this domain it may be said of the author, "Nihil tetigit, quod non ornavit."

From the brief and imperfect sketch which $\mathrm{I}$ have tried to give of recent advances in the solid geology of Scotland it will be admitted that restless activity and progress have been characteristic of the last quarter of a century. But we may expect that the conclusions accepted now will be rigorously tested by our successors, probably in the light of new discoveries and with more perfect methods of research. It is well that it should be so, for thereby our branch of science advances. Meanwhile, as we look back on the phalanx of geologists that Scotland has produced-to Hutton and Hall, Murchison and Lyell, Hugh Miller and Fleming, Nicol and Ramsay-and reflect on the services which they rendered to geology, we may hope that this record of progress may prove a fitting sequel to the labours of these illustrious men.

\section{SECTION G.}

\section{MECHANICS.}

Opening Address by Colonel R. E. Crompton, M.Inst.C.E., President of THE Section.

AT this the first meeting of the British Association of the new century I wish to lay before you some of the interesting problems presented by recent developments in means of locomotion on land which demand the best thoughts, not only of our engineers, but of everyone interested in the improvement in means of travelling and in the more rapid transit of goods.
During the seventy years which have passed since the introduction of railways in almost every country, passenger and goods traffic has developed itself to such an extent that almost every. one is interested in these questions; and of late years our attention has not been confined to railways only, but, owing to the invention of the cycle and motor-car, has also been directed to travel on our road-ways, which during the first fifty years of the railway era had somewhat fallen into disuse. I am not able, being limited to the length of this address, to deal with many of the interesting questions affecting our long-distance railways other than by referring to the probable early introduction of railways of a new type intended to attain a speed of 120 miles per hour and worked by electrical power. The railway race to Scotland of a few years back attracted the attention of the managers of American and Continental railways to railway speed questions, and we have seen during the last few years so great improvement in the speed of the trains and the comfort of the passengers in these countries that it appears that England has already been beaten in the matter of extreme railway speed, although it is probable that our railways still provide a larger number of rapid trains than either the American, German, or French do. But whether it be in England or in the countries I have mentioned, it appears that after all the speed limit of raiiways of the present system of construction is reached at about sixty-five or seventy miles per hour. Higher speed on level runs has undoubtedly been recorded, but it is not probable that anything greatly in excess of seventy miles per hour will be reached until our railway managers initiate an entirely new system of construction. The high-speed service that is now in contemplation, not only in England but in America and Germany, intends to attain speeds of more than one hundred miles per hour by providing electrical means of haulage sufficient to propel light trains consisting of one, or, at the most, a few cars ; and in order to render this service successful to run these light trains at short intervals of time, so in effecting this high speed the railways will give a service which more nearly resembles the tramway service than our present system of heavy express trains at infrequent intervals. This high-speed service of light trains at frequent intervals is well suited to electrical haulage, as it works generating machinery situated at fixed points to the best advan. tage and enables the best return to be obtained from the necessarily heavy capital cost of copper in the conductors which transmit the energy along the length of the line, as it is evident that if the speed be sufficient to ensure that each section of the line only carries one running train, the costs of the conductors will be in proportion to the weight of that train.

Great advantages have already been made in adapting electrical traction to long lengths of railways. The work already done by Brown Boveri, of Baden, in Switzerland, at first on the mountain railways and afterwards on the Burghdorf-Thun full-gauge line, the experimental work of Ganz and Co., of Buda-Pesth, and of Siemens and Halske at Charlottenburg, have already shown that the power problems are nearly all of them solved, so that we may feel confident that electrical engineers will very shortly surmount any power difficulties that still remain. But this highspeed railways problem at present presents certain unknown factors which can only be satisfactorily determined by the actual testing and working the lines when carrying passengers. I refer to those which deal with the increased oscillation, vibration, and noise to be expected from the extreme speeds. These matters must be met so as to give sufficient comfort and protection to the passengers, for if passengers are rendered uncomfortable by the extreme speed the service can never become popular, and on this last question depends the most important question of all, viz. the extent to which the travelling public are likely to make use of a high-speed railway service. In attempting to forecast this matter, although we meet inany business men who think it would be an undoubted advantage if the journeys between im. portant business centres occupied half the time they do at present, in the United Kingdom there are only a few journeys of sufficient length to make saving of time of great importance, but the case is far different in America and on the Continent, where the business centres are much further apart than they are here. I, as an English engineer, foresee that this topographical question will cause our English engineers to be at a disadvantage as compared with American and Continental ones, for it appears likely that the number and mileage of high-speed railways is likely to be far greater in America and on the Continent than in the United Kingdom. Before I entirely leave the subject of very high-speed railways, a rather curious speculation presents

NO. I664, vOL. 64] 
itself to us : this is whether the need for rapid communication between town and town may not eventually be supplied by highspeed motor-cars on roads specially prepared for them. Mr. Wells in his interesting forecast in the Fortnightly Review seems to think that the time is not far distant when all passenger traffic will be carried on special roads on motor-cars. That the advantages of carrying your family and loading up your belongings at your own door, in your own or a hired car, and transporting them without any change or handling of your baggage right up to the point where your journey ends, will be so great that even for comparative long journeys travellers will prefer it to the railway, and that our railways will eventually be relegated to carrying minerals and heavy goods. But, without going so far as Mr. Wells, it does seem probable that if only a few passengers require to travel between two business centres such as Manchester and Liverpool, and to occupy only half the time from door to door at present taken by the railway and the two terminal cab rides, it might be better to provide one of Mr. Wells' improved roads on which private owners could run their own cars, paying toll for the road, and on which a public service of cars would provide for those who did not own cars themselves.

I now propose to deal at somewhat greater length with what I think is a most important problem in locomotion, viz. that caused by the congestion of street traffic in our towns and by the undoubted difficulties which exist in carrying our workers to and from their homes in the country to their places of employment in our towns. A large proportion of the workers who during the latter half of the last century lived and worked in the country are now working in towns, although some of them still live outside in order to obtain the advantages of lower rents and of a healthier life for their families, and this last class is likely to increase largely. Those who have been responsible for the enlarging and improvements of our towns have done so much to make town life preferable to country life that the country is gradually being depopulated. The results we see in the increasing difficulties which the town authorities find in dealing with the water and sewerage questions, and in the increasing mass of vehicular street traffic, which makes some of our cities veritable pandemoniums. Luckily it seems that we are likely through the skill and energy of our engineers to meet these difficulties in more than one way. The cycle, which commenced as an amusement and went on as a fashionable craze, has now settled down into being the poor man's horse. The number of our working population that use the cycle for going to and from their work is already very large and is steadily increasing, and their use of the roads must be considered. Then came the motor-car, developed in France to such an amazing extent, and which seems now likely to be developed to an equal extent in this country. After many years of objecting to the use of the overhead trolley system, our'town authorities seem now to have determined that the only way of relieving street traffic is by an enormous development of electrical tramways, and on all sides we find the large towns rivalling one another in the extent of the tramway systems which they have either acquired or are laying down for themselves. It seems opportune now to point out that a great deal of mischief may accrue by this indiscriminate use of tramways, and for those who are considering these matters I bring forward a few facts which are worthy of notice. Of course, in new countries, or in new towns in old countries, where the roads are rough and bad, anything in the nature of a tramway using rails is an improvement on a roadway; but when we are dealing with cities which already possess well laid out and well paved streets on which all kinds of wheel traffic can be carried on with a minimum of rolling resistance, it seems wrong from an engineering point of view to break up the surface of these streets for the purpose of laying tramways, and for the following important reasons: Traffic carried on a roadway by vehicles, whether horse-drawn or by cycle or motor-car, differs from traffic carried on rails chiefly in that the former vehicles possess an important power, viz. that of overtaking, which is not possessed by the latter, that is to say that vehicles on the plain road surface can overtake a stopping or a slower vehicle going in the same direction without interfering with other vehicles, whereas on rails the vehicles going one way must always remain in the same relation to one another, so that the speed of vehicles on rails must always be regulated by that of other vehicles going in the same direction. Street tramways, for instance, must stop to set down and take up passengers: this limits the speed average and the number of vehicles per mile of track, for if there be not sufficient intervals between the vehicles they would have to stop and start nearly simultaneously. Thus the carrying capacity of the best modern electrical tramway is limited by this want of overtaking power. I have made careful inquiry from those who have great experience in tramways not only in this country but in America and on the Continent, and I find that it is generally admitted that the maximum carrying capacity of an electrical tramway in one direction is 4000 passengers per hour carried past any given point. I find that a full-gauge suburban or metropolitan railway crowded to its fullest extent cannot carry more than 12,000 passengers per hour. Now most of us have often seen large crowds taken away from a point of attraction by omnibuses and horse-drawn vehicles, and have noticed that the crowded omnibuses almost touch one another and yet can go at a fair rate of speed. In this case at eight miles per hour speed 14,000 passengers can be carried from a given point per hour.

Up to the present a public motor-car service has not yet been installed of any magnitude to enable us to compare the carrying capacity of motor-cars with that of horse-drawn omnibuses, but owing to the reduced length of motor-cars compared with that of omnibuses, and on account of their greater speed and greater control, motor-cars can now be built to deal with great crowds at an even higher rate per hour than that noted above. It appears certain, therefore, that although the provision of electrical tramways is undoubtedly an economical means os carrying passengers, yet that these tramways cannot be laid in existing thoroughtares without considerably reducing the total road carrying capacity at times of heavy pressure of traffic, and as it appears likely that either for the daily transport of the workers to and from their homes to places of employment, or for taking great crowds out into the country for pleasure purposes, a motor-car service carried out on well-made roads will compete favourably with, and in many ways may be preferable to, tramway service.

It must be remembered that the laying of tram rails not only blocks ordinary traffic, but in our most crowded streets it introduces dangers to all wheeled vehicles not on rails, motor-cars, and cyclists by the skidding of the wheels when they cross the line of rails, and these dangers are daily causing, and are still likely to cause, very serious accidents.

The increased road and street traffic and the development of new means of road locomotion have made imperative some modification of our existing system of roadway administration. Cycles, motor-cars, electrical tramcars, have been invented and put on roads which are maintained and worked exactly as they were seventy years ago at the commencement of the railway era when the population of the United Kingdon was half its present figure, and that of the large towns one-tenth of the present figure. During the I 50 years previous to the railway era the ancient tracks were gradually improved into tolerably efficient roads for coach and wagon traffic, but after the introduction of railways there was a complete cessation of improvement, as for fifty years after the railways started the old roads were equal to the farmers' and local traffic which the railways left for them but for the last twenty years the roads near to the great towns have been inadequate, and now that the cyclist and motor-caris travel over the whole of the roads of the country the neglect of our ancient roadway system is very apparent.

Although the urban populations have so greatly increased, the old coaching roads are still the only ones that exist; no main roads parallel to the old ones or alternative to them have ever been made. Towns which are now joined by railways grew out of small rows of houses built facing the main road; in fact, in many cases the road made the town. During the early part of the railway era, when the roads were so little used from coaching falling into disuse, encroachments on the roadway took place in and near the towns, such roads being now actually narrower and less suitable for traffic than in the coaching days: so that these towns which owe their existence to these roadways now put every impediment and hindrance to their use by the travelling public. What is needed is that towns situated on our main through roads should provide alternative routes, so that through travellers could, if they desired, avoid the crowded streets of the town. One method of providing such relief roads would be by by-laws providing that all building estates should set aside land for main roads. The building estates which are developed around our great towns never provide a road which can be used as a main line of thoroughfare, although by their very act of building

NO. I 664, VOL. 64] 
additional houses they cause additional congestion to the main roads. They lay out their roads to obtain quiet for those who live on the estate, and take every possible means to prevent their estate roads from taking a share of the main thoroughfare traffic.

Parliament must take in hand an improved administration of our highways by a comprehensive scheme. Far too many ancient main lines of thoroughfare, already too narrow for the traffic which is on them, are being blocked by having tramways laid on them; these cause the development of building estates, which throw additional traffic on to these thoroughfares. Apart from the roads themselves, the complicated conditions of street and road traffic demand careful regulation. Street traffic should be carried so far as possible by lines of vehicles driven as nearly parallel to one another as possible. The rule of the road, as it is called, and which is embodied in an Act of Parliament, 5 and 6 of William IV., which is commonly called the Highways Act, says that every vehicle is to keep as close as possible to the left, or near side of the road, except when overtaking another vehicle going in the same direction, and then it is to keep to the off side of the overtaken vehicle as closely as possible. As a matter of fact, everybody knows that this rule is habitually neglected by drivers who, whenever they get a chance, drive down the centre of the road, so that others who overtake them dare not do so on the wrong or near side, but must pass out far to the off side of the road, and consequently interfere with the traffic coming in the opposite direction. This neglect of the rule of the road causes a great waste of space immediately behind every vehicle, and is one of the chief causes of the limited carrying capacity of the streets in cities where the police do not attend to this important matter. It can be remedied by the existing police regulations being adhered to and insisted on by fixed-point constables, or by constables moving about on motor-cars or bicycles. Slow moving and frequently stopping vehicles are another cause of congested traffic. A great deal might be done by arranging that during certain hours much of the slower moving traffic is shunted into alternative routes, so as to be kept by itself. An increase in the speed of the street traffic is desirable; for the faster the vehicles travel the less the street is occupied by them. Motor-cars can safely travel at sixteen miles an hour, and, therefore, need only take half the time and occupy only half the street surface that an omnibus does when travelling at eight miles per hour. Such high speeds as these, which are desirable and perfectly safe for motor cars, cannot, however, be obtained unless some regulations are made as to the use of the roadways by foot passengers. There is no rule of the road for foot passengers-they pass one another on the footpath, or vehicles in the roadway, just as they please. No driver of a vehicle in the road who sees a foot passenger stepping into the roadway can ever tell with certainty what his movements will be. It will be no hardship to foot passengers to insist on their movements being regulated.

Much has been recently said and written on the subject of motor-cars and motor-wagons. It is generally admitted that there will be considerable scope for engineering skill and capital in their improvement and construction. It is by no means an easy problem to put into the hands of the public such a complicated piece of mechanism as a self-propelled carriage which has in most cases to be managed and driven by men who have had no special mechanical training. Motor-cars to be universally successful must be made so as to reduce to a minimum the liability to break down; repairs must be linited to the replacement of worn or damaged parts by other parts, which must be supplied by the manufacturers so that they can be readily put in by the unskilled users. That this can be done is shown by the success and universal use of typewriters, sewing machines, and bicycles : all of these are really complicated pieces of mechanism, but which are now in such general use and in everyone's hands. In these cases, however, the organised manufacture of machines with thoroughly interchangeable parts, or components as it is the fashion to call them, has only been developed after the type of machine had settled down, and this up to the present cannot be said of the motor-car or motor-wagon. Up to the present the development of these cars has gone on on several lines. The development in France, which so far has led the world, has been principally in the direction of the use of light motors driven by petrol spirit. Again to France we owe the flash boiler of Serpollet, which assists the use of steam engines for this purpose.

At first sight steam, with the complications of boiler, engine, and condenser, does not appear likely to compete favourably with the simpler spirit motor, but for heavier vehicles, where steady heavy pulling power is of importance, up to the present no internal combustion motor has competed with it. The Americans, with their usual skill and power of rapidly organising a new manufacture, have already turned out a very large number of steam-driven motor-cars, which are so largely in use in unskilled hands that it shows that they have already solved the problem to some extent.

The directions in which the two classes of motors require further development are, for the internal combustion motors, the satisfactory and inodorous use of the heavier oils, and in this perhaps Herr Diesel may help us with his wonderfully economical motor improvements in the clutch mechanism, for with all internal combustion engines up to the present it has been found impossible to start the motor when coupled to the driving-wheels of the car; and in the case of the steam motor the simplification of the boiler, the boiler feed mechanism, the inodorous and noiseless burning of heavy oils as fuel, improved condensers, methods of lubricating the pistons and valves so as to avoid oil passing back to the boiler with the condensed water, and the rendering of all processes of boiler feed and fuel feed mechanism completely automatic so as not to require the attention of the driver. On points common to both classes, although much has been done, further improvement is required in the methods of transmitting the power from the motor to the driving-wheels. In the case of the steam cars, where this has been done by single reduction, using chain, pinion, and sprockets, very efficient and noiseless transmission has already been obtained, but up to the present in most of the internal combustion engines where more than two cylinders have to be employed, it has been found necessary to arrange the crank shaft of the motor at right angles to the axle of the drivingwheels, so that part of the transmission having to be through bevel gear, this part has up to the present always been noisy. In the providing of noiseless and efficient cilain driving, the manufacturer of cars has gained greatly by the high degree of perfection to which these chains had already attained for bicycle work.

The recent great road races which have taken place in France and elsewhere have shown that the motor-car can be driven safely at a very high speed, already reaching in some cases seventy miles an hour; but to render this capacity for high speed useful, not only must special roads be provided on which these high-speed cars can travel without danger to others and with least slip and wear and tear of tyres, but a great deal requires to be done in the improvement of the pneumatic tyres, which at present get excessively hot, and therefore damaged by these high-speed runs. At these high speeds the mechanical work done on the material of which the outer covers of pneumatic tyres are composed is excessively high. It can probably be reduced by increasing the diameter of the wheels, but, of course, at the cost of increased weight and, to some extent, of stability, for the side strains on the wheels of these cars when swinging round curves of sharp radius are very great.

Another direction in which mechanical invention is required for the wheels of motor cars and wagons is a shoeing or protection of hard material of easily renewable character which can be firmly and safely attached to the outside of the tyre covers to take the wear and cutting action caused by the driving strain and by the action of the breaks on sudden stops.

The late R. W. Thomson, of Edinburgh, made good progress some thirty years ago in providing steel shoeing for the solid rubber tyres he then used, and the problems of providing the same for pneumatic tyres ought to be no harder than those he then successfully encountered.

One of the topics which has been most strongly discussed during the last year has been the position which this country holds relatively to other countries as regards its commercial supremacy in engineering matters. A few years back we were undoubtedly ahead of the world in most branches of mechanical engineering, but owing to the huge development of mechanical engineering in America and Germany, we are certainly being run very hard by these countries, and everyone is looking for means to help us to regain our old position. In endeavouring to learn from America we see that, although the workmen in that country receive higher wages than they do here, and although the cost of some of the materials is higher than it is here, their manufacturers manage to deliver engines, tools, and machinery of all classes of excellent quality at a price which appears to our

No. 1664 , vor. 64] 
manufacturers to be marvellously low. When we look into the matter we find that the chief difference between the manufacturer of America and the manufacturer at home is that, whether it be steam-engines, tools, agricultural machinery, or electrical machinery, the American invariably manufactures goods in large quantities to standard patterns, whereas we rarely do so here, at any rate to the same extent. Where we turn out articles by the dozen the American turns them out by the hundred. This difference in the extent to which an article is reduplicated is caused by the Americans having realised to a far greater extent than we have the advantage of standardisation of types of machinery. They have felt this so strongly that we find in America that work is far more specialised than it is here, so that a manufacturer as a rule provides himself with a com. plete outfit of machinery to turn out large numbers of one article. He lavishes his expenditure on special machinery to produce every part sufficiently accurate to dimension to secure thorough interchangeability; consequently the cost of erecting or assembling the parts is far less than it is here. One reason why the American manufacturer has been able to impose on his purchasing public his own standard types, whereas we have not been able to do so, is that very rarely in America does a consulting engineer come between the manufacturer and the user, whereas here it is the fashion for the majority of purchasers of machinery to engage a consulting engineer to specify and inspect any machinery of importance. By this I do not impute any blame to our consulting engineer; he considers the requirements of his client, and insists that they are to be adhered to as closely as possible; to him the facility of the production of articles in large quantities is of no moment. In America it seems to be understood by the purchaser that it is a distinct advantage to everyone concerned, both manufacturer and purchaser, that the purchaser should to some extent give way and modify his requirements so as to conform with the standard patterns turned out by the manufacturer. Although manufacturers all hope for this simplification of patterns, yet, for the reasons I have given, it will be some time before their hope is realised. But on other matters it is quite possible for manufacturers to combine, so as to obtain some standardisation of parts which they manufacture which will reduce costs and be of advantage to everyone concerned. Many years ago Sir Joseph Whitworth impressed on the world the importance in mechanical engineering of extreme accuracy, and of securing the accurate fit and interchangeability of parts by standard gauges. But in spite of his idea being so widely known and taught, how seldom it has been acted upon to the extent that it should be. We pride ourselves on having all our screws made of Whitworth standard, and yet how many of the standard bolts and nuts made by different makers fit one another? I myself have sat on a committee of this Association which was called together twenty years ago, with Sir Joseph Whitworth as a member of it, to fix on a screw gauge which would be a satisfactory continuation of the Whitworth screw gauge down to the smallest size of screw used by watchmakers. ${ }^{2}$ It has taken all these years to carry out the logical outcome of Sir Joseph Whitworth's original idea, viz. the providing of standards to be deposited in care of a public authority to act as standard gauges of references. The complete interchangeability of parts which I have above referred to, and which is so desirable in modern machinery, can, of course, be obtained within the limits of one works by that works providing and maintaining its own standards to a sufficient degree of accuracy. But if the articles be such as watches or bicycles, motor-cars, \&c., it is very desirable that all parts liable to require replacement should be made by all manufacturers to one standard of size, and in order that the gauges required for this purpose should all be exact copies of one another it is necessary that they should be referable to gauges deposited either with the Board of Trade or with some body specially fitted to verify them and maintain their accuracy.

Up to the present the Board of Trade has dealt with the simple standards of weight, capacity, and length, but in other countries National Standardising Laboratories have been provided, viz. by the Germans at their Reichsanstalt at Charlottenburg, and with the happiest results; here at last, through the exertion of the Council of the Royal Society, our Governmen has been moved to give a grant in aid and to cooperate with the Royal Society to establish a National Physical Laboratory for this country. About ten years ago Dr. Oliver Lodge gave

1 A report of this committee will come before you during this meeting. NO I664, VOL. 64] the outlines of a scheme of work for such an institution. Later Sir Douglas Galton, in his Presidential Address to this Association, called attention to the good work done by the Germans and the crying need that existed for such an institution in this country. The matter has since progressed. A laboratory is already in existence, and will soon be at work, at Bushey House, Teddington; it is a large residence, which was once occupied by the late Duke of Clarence and afterwards by the Duc de Nemours. It will make an admirable laboratory, as it has large and lofty rooms and a vaulted basement in which work can be carried on where it is important to secure the observer against changes of temperature.

The aims of a National Physical Laboratory have been well put forward by Dr. Glazebrook in a recent lecture at the Royal Institution, in which he points out how little science has up to the present come to be regarded as a commercial factor in our commercial world. The position of manufacturers of all classes must be helped and improved by a well-considered series of investigations on the properties of materials, measurements of forces, and by the careful standardisation of and granting certificates to measuring apparatus of all classes. Until the question is fairly faced and studied, few manufacturers realise how helpless individual effort or individual investigations must be when compared with comprehensive and continuous investigations which can be carried on by a National Laboratory so as to deal with the whole of each subject completely and exhaustively, instead of each investigation being limited by the temporary need of each manufacturer or user.

As an example Dr. Glazebrook showed how much has been done at Jena and afterwards at the Reichsanstalt in the development of the manufacture of glass used in all classes of scientific apparatus. The German glass trade has benefited enormously from these investigations. The microscopic examination of metals, which was begun by Sorby in 1864 , has been much worked at by individual investigators in this country, but its further development, which is probably of enormous importance to arts and manufactures, is clearly the duty of a National Laboratory. We owe much to the investigations of the Alloys Research Committee of the Institution of Mechanical Engineers ; but, again, this is work for the National Laboratory. As regards the measurement of physical forces how little is accurately known of the laws governing air resistance and windpressures, and the means of measuring them. Who can formulate with any certainty a law for the air resistances likely to be met with at speeds in excess of eighty miles an hour, the importance of which I have already noticed?

I have already alluded to the verification, care, and maintenance of ordinary standard gauges of accuracy. In this electrical age the accuracy of electric standards is of supreme importance.

These are only a few of the directions in which we can foresee that the establishment of a National Physical Laboratory will be of the greatest use and assistance to our country in enabling it to hold its own in scientific and engineering matters with its energetic rivals. The work has been commenced on a small scale, but it is to be hoped that its usefulness will become at once so evident and appreciated that it will soon be developed so as to be worthy of our country.

\section{NOTES.}

AN expedition to Patagonia has been undertaken, under the auspices of the French Minister of Public Instruction, by M. A. Tournouër, whose purpose is to continue his study of the Tertiary mammals of South America.

THE last number received of the Victorian Naturalist states that, on July 19, Prof. Baldwin Spencer telegraphed from Alice Springs that his expedition had finished its work at Barrow Creek, where six weeks had been spent among the Kaitish and Ummatjera tribes. Much valuable information relating to tribal organisations, totemic systems, \&c., had been collected, and a fine series of photographs of sacred ceremonies, types of natives, \&c., secured. The next main camp was to be formed at Tennant's Creek, about 150 miles further north (latitude $19^{\circ} 30^{\prime} \mathrm{S}$.). The members of the party were in excellent health, and well pleased with the results of their work. 